\title{
Is the East Australian Current Causing A Marine Ecological Hot-Spot and An Important Fisheries near Fraser Island, Australia?
}

Daniel Brievaํㅜ, Joachim Ribbe ${ }^{1}$, and Charles Lemckert ${ }^{2}$

${ }^{1}$ International Centre for Applied Climate Sciences (ICACS), University of Southern Queensland, Toowoomba 4350 Queensland, Australia ${ }^{2}$ Griffith University, Griffith School of Engineering, Gold Coast, 4222, Queensland, Australia,

Corresponding author: Joachim.Ribbe@usq.edu.au

Revised Manuscript for Estuarine, Coastal and Shelf Science

Toowoomba, 8 December 2014 
Abstract

The distributions of Chlorophyll-a (Chl-a) blooms near the Fraser Island continental shelf along the east coast of Australia were analysed for the period 2002-2012. The blooms were found to exhibit two distinct quasiclimatological patterns. The first pattern was a broad near-coast mid-shelf distribution that prevailed from about March to July each year. The second pattern was established due to re-occurring outer-shelf Chl-a blooms southeast of Fraser Island from about August to February. The outer-shelf Chl-a bloom concentration maxima appeared to be higher than those associated with the near coast pattern. Both distributions were found to be characterised by significant year-to-year variability in the number of total blooms, the length of blooms and the Chl-a bloom concentration maxima. The physical cause of the outer-shelf Chl-a concentration maxima was of particular interest, since this location overlaps with a region previously identified as a key eastern Australian marine ecological site and important fisheries. In this analysis, we found that the area also overlaps with a hot-spot in EAC-generated bottom layer stress, which appears to be the main driver of the "Southeast Fraser Island Upwelling System".

Keywords: Chlorophyll-a, East Australian Current, Southeast Fraser Island Upwelling System, Western Boundary Current, bottom layer stress 


\section{Introduction}

Previous studies of Australian coastal upwelling systems and underlying physical processes have focused on both western and eastern boundary current regions, as well as the Great Australian Bight (GAB), where upwelling supports Australia's most significant sardine fisheries (e.g. Ward et al, 2006). The earliest hydrographic data documenting wind-driven upwelling episodes in the GAB date back to 1938/39 (in Lewis 1981). Kämpf et al. (2004) found that about two to three wind-driven upwelling events occur simultaneously in three centres across about $800 \mathrm{~km}$ of the eastern GAB shelf during the Southern Hemisphere summer. Peak Chl-a concentrations of $>4 \mathrm{mg} \cdot \mathrm{m}^{-3}$ were reported, and events lasted about one week each. McClatchie et al. (2006) proposed a GAB upwelling model that limits the original source of upwelled nutrient water to the most eastern of all GAB upwelling centres near Kangaroo Island, where an upwelled nutrient-rich sub-surface pool continues to supply the surface ocean along the eastern GAB shelf during subsequent upwelling events. Middleton et al. (2007) investigated interannual variability of GAB events and Nieblas et al. (2009) proposed a simple model to predict GAB Chl-a variability. Middleton et al. (2014) contrasted upwelling and enhanced marine productivity along the narrow eastern and western shelfs of the GAB. All-year round downwelling was proposed as an upwellingsuppressing mechanism that reduces marine productivity in the central GAB. Kämpf (2014) continued to argue for the existence of several distinct GAB upwelling centres, adding a fourth upwelling centre located on the western 
Tasmanian shelf, thus expanding the previously identified GAB upwelling system Kämpf et al. (2004) further to the east.

The two major flows of the Australian eastern and western boundary current systems are the southward flowing Leeuwin Current (LC) and the East Australian Current (EAC). Studies by Hansen et al. (2005), Pearce et al. (2006), Rennie et al. (2009), Rossi et al. (2013) and Xu et al. (2013) investigated upwelling along the coast off Western Australia. Hansen et al (2005) studied summer upwelling, when the otherwise downwelling southward flowing LC is replaced along the coast by the equatorward-flowing Ningaloo and Cape Currents. Pearce et al. (2006) expanded on this and provided insight from the first long-term (27 month) field study of physical ocean processes including upwelling off Western Australia. Rennie et al. (2009) studied upwelling near Perth, Western Australia, using the Regional Ocean Model System (ROMS) and found that local sporadic upwelling was driven by a combination of physical processes including wind, mean current flow and eddy activity. A similar approach was used by $\mathrm{Xu}$ et al. (2013) to study episodes of upwelling near Ningaloo Reef, while Rossi et al. (2013) used 15 years of satellite data to quantify upwelling along sections of the west Australian coast. Favourable conditions ranged from a maximum of 140 days near Ningaloo to just a few days per year for locations in the south.

Along the EAC-influenced eastern coast of Australia, studies by Andrews and Gentien (1982), Griffin et al. (1987), Hallegraef and Jeffrey (1993), Middleton et 
al. (1994), Oke and Middleton (2000, 2001), Roughan and Middleton (2002, 2004), Weeks et al. (2010), Thompson et al. (2011), Wood et al. (2012), Schaeffer et al. (2013), Everett et al. (2014), Armbrecht et al. (2014), Schaeffer et al. (2014) and Rossi et al. (2014) provided significant insight into the location, frequency and the physical mechanisms of Australian east coast upwelling. Here, the prevailing south-easterly trade winds are generally upwelling unfavourable (Thompson et al., 2011). Therefore, the role of the EAC driven upwelling, in combination with sporadic favourable northerly winds, plays an important role in delivering nutrient-rich and cold water to the surface (Rossi et al., 2014). Hallegraef and Jeffrey (1993) and Oke and Middleton $(2000,2001)$ stressed the role of this current-driven upwelling associated with an encroachment of the EAC on the coast that is modified by local bathymetry (Roughan and Middleton, 2004). Most recently, Armbrecht et al. (2014), Everett et al. (2014), Schaeffer et al. (2014), and Rossi et al. (2014) quantify upwelling favourable conditions and the relative contribution made by windand current-driven upwelling for the east coast south of about $28^{\circ} \mathrm{S}$. Rossi et al. (2014) linked field data from about 30.3 oS (near Coffs Harbour, NSW) and historical observations from about 33.9 oS (near Sydney, NSW) with climatological data to quantify wind- and current-driven upwelling processes and their relative contributions to surface layer nutrient enrichment in those locations. For both locations, Schaeffer et al. (2014) documented changes in shelf water characteristics that appear to be linked to EAC fluctuations on time scale of $90-100$ days. Further to the north at about $18.5^{\circ} \mathrm{S}$, Andrews and Gentien (1982) found nutrients, cold, and salty water being delivered to the 
Great Barrier Reef ecosystem due to upwelling. These also appeared to fluctuate on about a 90-day time scale, most likely due to shelf waves propagating along the continental shelf. The well-studied transient Capricornia eddy located at the southern end of the Great Barrier Reef ( 153 E, $23^{\circ} \mathrm{S}$ ) was found to drive cold water and nutrients to the surface (Weeks et al., 2010). Mao and Luick (2014) expanded on this finding that both wind and mean EAC flow contributed, along with the upwelling process in the Capricornia eddy region.

In this paper, an analysis of the distribution of remotely sensed ocean colour and estimated Chl-a to the east and southeast of Fraser Island, Australia, is presented for the period 2002-2012. We expanded on the earlier studies by focusing on a less well-studied region along the east Australian coast located to the southeast of Fraser Island (Figure 1). Our aim was to: (1) describe the frequency and spatial distribution of sporadic Chl-a events with a focus on the outer-shelf region; (2) quantify the contribution made by upwelling favourable bottom stress $\left(\tau_{y b}\right)$ and wind stress $\left(\tau_{y w}\right)$ to Chl-a blooms; and (3) identify the likely physical drivers that appear to support an important key Australian coastal marine ecosystem and fisheries.

\section{Description of the study site}

The study site is situated between recently investigated EAC upwelling centres, and includes one of eight key marine ecological provinces and 
important fisheries of Australia's eastern ocean (e.g. Young et al., 2011, Dambacher et al., 2012). Its location is to the south of the Great Barrier Reef Lagoon, and east and southeast of Hervey Bay and Fraser Island (about $153^{\circ}$ to $154^{\circ} \mathrm{E}$ and $24^{\circ} \mathrm{S}$ and $27^{\circ} \mathrm{S}$, see Figure 1). It is here that the EAC forms due to the merging of several outflows from the Coral Sea and the South Equatorial Current. The merged flow intensifies and narrows to produce a swift southward-flowing western boundary current that closely follows the continental shelf (Suthers et al., 2011). From about $25^{\circ} \mathrm{S}$ southward, the EAC shows strong seasonal variability with flows ranging from $\sim 7 \mathrm{~Sv}$ during the Southern Hemisphere Winter to 16 Sv in Summer (Ridgway and Godfrey, 1997). The climate of the region is subtropical, with most rainfall occurring during the Summer months, but is also subject to significant interannual variability (Murphy and Ribbe, 2004).

During a September 2004 survey, Young et al. (2011) observed a Chl-a concentration maximum in this region, which is a hot-spot for the eastern tuna fisheries. Dambacher et al. (2012) argued that high marine productivity results from a series of not-well-understood upwelling processes. This includes Ekman fluxes in both bottom (Middleton, 1994) and surface layers (Rossi et al., 2014), and possible upwelling cold-core eddy activity (Young et al., 2011; although the eddy referred to was situated to the east of the EAC, i.e. outside the study site considered in this paper). In addition to upwellingdriven surface layer nutrient enhancement leading to Chl-a blooms, it is noted that, north- and southeast of Fraser Island, surface water nutrient enrichment 
has other potential sources. These include tidal flushing and advective export of high-nutrient coastal mangrove water (Middleton et al., 1994), densitydriven outflows of Hervey Bay Water (Ribbe, 2006), river-runoff (Pearce et al., 2006; Brodie et al., 2010), and dust storms (e.g. Gabric et al., 2010).

Near Double Island Point, south of Fraser Island (Figure 1), where the core of the EAC closely follows the continental shelf, Middleton et al. (1994) found physical evidence of current-driven upwelling during a field survey. It was hypothesised that strong bottom Ekman layer flux resulted in the observed uplift of nutrient-rich (phosphate, nitrate and silicate) water onto the shelf. Gräwe et al. (2010) found evidence of a sporadic upwelling event just to the north of Sandy Cape at $24.5^{\circ} S$ in hydrography data from a Hervey Bay survey during December 2007. Rossi et al. (2014) focused their analysis of eastern coastal upwelling on a region south of $28^{\circ} \mathrm{S}$ using 10 years of remotely sensed wind data. It was found that upwelling favourable winds may occur 3-6 days per month on average during the August to December period, at the same time when current-driven upwelling is at a maximum, and less than 2 days per month during other months that appear to be dominated by wind-driven downwelling conditions. It is noted that Middleton et al. (1994) made their hydrographic observations indicating upwelling during May; thus a period that has a much lower frequency of wind- and current-driven favourable conditions.

\section{Data and method}




\subsection{Ocean colour and Chlorophyll-a data}

MODerate resolution Imaging Spectroradiometer (MODIS) measurements of ocean colour obtained with an Earth-orbiting satellite based sensor were processed by the Australian Commonwealth Scientific and Industrial Research Organisation (CSIRO) to provide estimates of the daily Chl-a concentrations $\left(\mathrm{mg} \cdot \mathrm{m}^{-3}\right)$ via the Australian Integrated Marine Observing System (IMOS 2013). O'Reilly et al. (2000) details how MODIS measures reflected sunlight and how measurements are used to derive Chl-a concentrations. The OC3 algorithm (IMOS 2013) was used to produce the Chla concentrations with a spatial resolution of $0.01^{\circ}$, and is analysed in this paper for the period $09 / 08 / 2002$ to $31 / 12 / 2012$. The historical and average distribution of the Chl-a concentration in conjunction with Sea Surface Temperature (SST) obtained from the same source with the same temporal and spatial resolution is described in Section 3 of this paper.

The total number of daily images available for this study was 3729 (see Table 1). With about $63 \%$ of all images having a $50 \%$ or larger cloud coverage, less than about $1 / 3$ of all images (or 1399 images, i.e. $37 \%$, see Table 1 ) appeared to be useful. These could be classified into one of the two characteristic patterns that are discussed in Section 3.

During the period of study, a major dust storm occurred in September 2009 
during the Australian Millennium drought (Aryal et al., 2012). Although dust storms occur frequently and lead to dust deposition and surface layer nutrient enrichment (Gabric et al., 2010), the September 2009 event is the only one associated with a significant maximum in the Chl-a concentration across the whole of the study region. This resulted in one cloud-free image being excluded from further analysis since it impacted significantly on average conditions. Days before and after this event were also not considered due to more than $50 \%$ of the image being cloud covered.

Shallow coastal shelf water limits the usability of remotely sensed Chl-a due to a range of factors including bottom albedo, suspended sediment and coastal turbidity (Moses et al., 2012). Bottom albedo could lead to an inverse relationship between Chl-a and water depth (e.g. Cannizzaro and Carder, 2006). Dambacher et al. (2012) limited their analysis to the range of $0.15-0.25$ $\mathrm{mg} \cdot \mathrm{m}^{-3}$. This is above the Coral Sea background value of about $0.15 \mathrm{mg} \cdot \mathrm{m}^{-3}$ (Condie and Dunn, 2006), and also excluded higher near coast values in their analysis. Everett et al. (2014) removed near coast Chl-a concentrations due to possible influences from albedo and river discharges. Here, the limitation of remotely sensed Chl-a concentrations was considered by restricting the interpretation and analysis to water deeper than $40 \mathrm{~m}$. The $40 \mathrm{~m}$ depth contour is shown in Figure 1, and indicates the approximate optical depth in shallow coastal waters (Zhang et al., 2011). In shallower water, light may penetrate the water column and is reflected from bottom sediments. An example of this is discussed in Section 3. Generally, analysed Chl-a 
concentrations outside the near-coastal zone (depth $>40$ ) were well above the background value of $0.15 \mathrm{mg} \cdot \mathrm{m}^{-3}$ (Condie and Dunn, 2006), and sometimes were significantly larger than the values considered by Dambacher et al., (2012) with maxima of about 5-6 $\mathrm{mg} \cdot \mathrm{m}^{-3}$ (see results in Section 3 below).

The term 'sporadic high Chl-a events' was used when the Chl-a concentration was larger than the derived maximum background Chl-a concentration of 0.2 $\mathrm{mg} \cdot \mathrm{m}^{-3}$. In this analysis the highest mean background value $\left(\sim 0.25 \mathrm{mg} \cdot \mathrm{m}^{-3}\right)$ was found for the month of July (see section 3.1.1, Figure 2). Maximum Chl-a concentrations during sporadic high Chl-a events were similar to those found in southeastern Pacific Ocean coastal regions, e.g. Echevin et al., (2008) reported maximum values of $5-10 \mathrm{mg} \cdot \mathrm{m}^{-3}$.

\subsection{Bottom stress data}

Version 3.5 of the Bluelink reanalysis experiment (referred to as BRAN3.5) provided the velocity field in order to determine alongshelf bottom stresses for the region east to southeast of Fraser Island. Bluelink is an ocean modelling and data assimilation system. It is quasi-eddy resolving in the Australian region where it has a resolution of about $10 \mathrm{~km}$. The ocean model is based on the Modular Ocean Model - MOM (Oke et al., 2008). Previous versions of regional Bluelink data were used to compute alongshelf bottom stresses to investigate upwelling along the Australian southeast coast off New South Wales (e.g. Everett et al., 2014). The alongshelf bottom stress originates 
from the interaction between near-bottom currents caused by the wind-driven EAC flow, current encroachment, and eddy activity and a rugged bathymetry (e.g. Everett et al., 2014; Aguiar et al., 2014). It is associated with a cross-shelf transport of water, subsequent upwelling and nutrient transport toward the surface layer (Oke and Middleton, 2000).

The alongshelf bottom stress $\tau_{\mathrm{yb}}\left(\mathrm{m}^{2} \mathrm{~s}^{-2}\right)$ was computed following the theory described by Oke and Middleton (2000) and applied e.g. by Everett et al. (2014) and Schaeffer et al. (2014):

$$
\tau_{y b}=C_{D} v_{b} \sqrt{u_{b}{ }^{2}+v_{b}{ }^{2}}
$$

where $u_{b}\left(\mathrm{~m} \cdot \mathrm{s}^{-1}\right)$ and $v_{b}\left(\mathrm{~m} \cdot \mathrm{s}^{-1}\right)$ are west-east and south-north bottom boundary layer velocity components obtained from the Bluelink reanalysis model, and $C_{D}$ is the drag coefficient. A value of 0.003 was used in the above formula to computed bottom shear stress (Kowalik and Murty, 1993), which is similar to the value applied by Everett et al. (2014). Bottom shear stresses computed here are of the same order of magnitude $\left(10^{-4}\right)$ than the data reported by Oke and Middleton (2000). The alongshelf bottom stress was computed using the BRAN 3.5 south-north bottom boundary layer velocity. The velocity component was not rotated to the alongshore direction (e.g. Everett et al. 2014) which potentially underestimated the alongshelf bottom stress. However, the difference was only small for the region of maximum bottom shear stress along the shelf edge to the south of Fraser Island (Figure 7). A 
rotated velocity would have increased the bottom shear stress for this region by $\sim 10 \%$.

\subsection{Wind stress data}

Wind measured at the Sandy Cape Lighthouse at the north end of Fraser Island (Figure 1) and data provided by the Australian Bureau of Meteorology represents the closest coastal station data for the region of interest. Three- or six-hourly data were averaged into daily data, with gaps in the daily observational records making up about $4 \%$ for the period 2002-2012. The formulations provided by Wood et al. (2012) were used to estimate the wind speed $\mathrm{W}\left(\mathrm{m} \cdot \mathrm{s}^{-1}\right)$ at $10 \mathrm{~m}$ height and wind stress. This was then used to estimate sea surface level wind stress $\tau_{\mathrm{yw}}\left(\mathrm{N} \cdot \mathrm{m}^{-2}\right)$ from the following formulation:

$$
\tau_{y w}=C_{a} \rho_{a} v_{w} \sqrt{u_{w}{ }^{2}+v_{w}{ }^{2}}
$$

$u_{w}\left(\mathrm{~m} \cdot \mathrm{s}^{-1}\right)$ and $v_{w}\left(\mathrm{~m} \cdot \mathrm{s}^{-1}\right)$ are west-east and south-north components of wind velocity. $C_{a}$ is a velocity dependent drag coefficient (see Wood et al., 2012) and $\rho_{a}$ is the density of air with $1.3 \mathrm{~kg} \cdot \mathrm{m}^{-3}$.

\section{Results}

In describing the distribution of Chl-a in shelf waters, reference was made to 
inner-, mid-, and outer-shelf. The term inner-shelf was used here in reference to the near-coast region with water depth $<40 \mathrm{~m}$, where Chl-a may be overestimated (see above). The mid-shelf (depth $>40 \mathrm{~m}$ ) was characterised by distinct periodic Chl-a maximum events referred to below as near coast midshelf blooms or Pattern 1 (referred to as P1). A characteristic of the outer-shelf $(<200 \mathrm{~m})$ region are the Southeast Fraser Island blooms that established a Pattern 2 (referred to as P2). The distribution of these two patterns and their characteristics is described and discussed in the following sections.

\subsection{Analysis of the Chl-a distribution}

In the following sections, the distribution of IMOS provided Chl-a $\left(\mathrm{mg} \cdot \mathrm{m}^{-3}\right)$ data were presented and described: (a) in form of a monthly climatology; (b) for characteristic individual sporadic high Chl-a events; and (c) in terms of a composite event climatology. The latter composite was derived from sporadic high Chl-a events and establishes two distinct quasi-climatological features for this part of the Australian east coast. These are captured schematically in Figure 1 (see shaded areas). Individual sporadic high Chl-a event concentrations have maxima between about $1-6 \mathrm{mg} \cdot \mathrm{m}^{-3}$, which is similar to previously observed Chl-a blooms (e.g. Hallegraef and Jeffry, 1993).

\subsubsection{Monthly climatological Chl-a concentration}

The monthly averaged Chl-a concentration estimates $\left(\mathrm{mg} \cdot \mathrm{m}^{-3}\right)$ for the period 
2002 to 2012 are presented in Figure 2. The most prominent feature is the outer-shelf maximum in the Chl-a $\left(\mathrm{mg} \cdot \mathrm{m}^{-3}\right)$ concentration (or estimate) to the east and southeast of Fraser Island. The feature starts to evolve in about August and appears to be fully developed in spatial extent and maximum concentration (climatological average is in the order of $\sim 2-3 \mathrm{mg} \cdot \mathrm{m}^{-3}$ ) during September and October. Note that the average values shown in Figure 2 are lower than those observed for individual events (see Figures 4 and 5). From about November, the pattern then narrows and decreases in size and concentration, with only a weak feature detectable in February before its complete disappearance.

From about March to July, elevated Chl-a concentrations are found over most of the mid-shelf, i.e. in water deeper than $40 \mathrm{~m}$, with values in the range of $\sim 0.5$ to $\sim 1 \mathrm{mg} \cdot \mathrm{m}^{-3}$ (Figure 2). The levels decrease towards the east to well below the $0.1 \mathrm{mg} \cdot \mathrm{m}^{-3}$, which is close to the open ocean background Chl-a concentrations (Condie and Dunn, 2006). The fully developed zone of elevated inner-shelf Chl-a appears to have a width of approximately $50-60 \mathrm{~km}$ during July, and extends well beyond the $40 \mathrm{~m}$ depth contour. The near-coast mid-shelf bloom (P1) retreats when the out-shelf Southeast Fraser Island bloom (P2) starts to evolved in about August. Throughout the year, the most eastern extent of elevated Chl-a appears to be limited to water depth of less than $200 \mathrm{~m}$ (Figure 1).

It should be noted that any apparent sporadic high Chl-a events in shallow 
water $(<40 \mathrm{~m})$ may not be due to actual water column Chl-a, but could be due to suspended sediment, bottom sediment albedo and high water turbidity in coastal water. An example of this effect (in this case most likely due to bottom sediment albedo) is possibly seen to the north of Sandy Cape, Fraser Island (see Figure 1). The Break Sea Spit forms a submerged sandbar with water depths of about 4-5 m and less. It extends the island for an additional $40 \mathrm{~km}$ northward and leads to an apparent maximum in the Chl-a, with its pattern aligned with the Break Sea Spit. However, it is also possible that the elevated concentration is 'real' Chl-a, since some individual events (see Figure 5, events on 1 December 2008 and 15 October 2009) were characterised by a negative SST anomaly due to upwelling. These events would be evident in the monthly climatology.

Further, in close proximity to the coast, i.e. the inner-shelf, run-off from the major rivers in the region (e.g. Mary River discharging into Hervey Bay, see Ribbe, 2006) could cause sporadic high Chl-a events due to the supply of nutrients from terrestrial sources in the catchment systems and from coastal mangrove regions. Mostly, the flow of this water is limited to an inner-shelf zone of $<10 \mathrm{~km}$ along the western shoreline, but is likely contributing to the near shore high Chl-a concentrations shown in all months. However, the main focus of the present analysis was on the sporadic events that drive the outershelf P2 and was described further below.

In summary, the January to December climatological Chl-a $\left(\mathrm{mg} \cdot \mathrm{m}^{-3}\right)$ 
distributions shown in Figure 2 were derived as monthly composites from about 10 years of satellite imagery. Two distinct distributions appear to characterise two different periods of the year. These are a result of individual multi-day episodes or events of elevated Chl-a concentrations that typically last several days with maximum concentrations of about $1-6 \mathrm{mg} \cdot \mathrm{m}^{-3}$. These individual events were discussed further in the following section.

\subsubsection{Characteristic sporadic high Chl-a events}

The spatial distribution of a small number of sporadic high Chl-a events was not consistent with the P1 and P2 distributions. This included those associated with high river discharges due to storms and periods of high river run-off, primarily during the spring and summer months. Further, during four Chl-a blooms in the region, both the near coast mid-shelf (P1) and the outer-shelf Southeast Fraser Island (P2) distribution occurred concurrently. One of these was the event documented by Young et al. (2011, in their Figure 2) during a September 2008 field survey. This was also the period (usually July to September, see Figure 2) when other events with co-existing patterns did occur.

The total number of events categorised as near-coast or mid-shelf blooms (P1) and outer-shelf Southeast Fraser Island blooms (P2) is 67 and 76 multi-day elevated Chl-a events, respectively (Table 1). The total number of days classified as P1 and P2 is 436 days and 585 days respectively; thus an estimate 
for the length of an individual P1 and P2 events is about 7-8 days. It should be noted that the total number of days that could be classified into these two patterns is potentially larger, since frequent cloud coverage prevented detection of the accurate onset or termination of an event. The total number of classified events per month is shown in Figure 3, with P1 dominating the March to July period (78 \% of all P1 events occur during this period) and P2 clearly dominant from about August to December (75 \% of all P2 events occur during this period).

Representative examples of eight individual episodes of high Chl-a concentrations categorised into near-coast mid-shelf (P1) and Southeast Fraser Island blooms (P2) with corresponding SST are shown in Figure 4 (P1) and Figure 5 (P2). The focus of the discussion is on elevated Chl-a concentration water depth greater than $40 \mathrm{~m}$, i.e. the mid-to-outer-shelf region. This excludes Hervey Bay, with water depth less than 30 m (see 40 m contour line).

P1 events (Figure 4) occur each year primarily during the months March to July as per climatology (see Figure 2). These high Chl-a events are all limited in extend to the shelf, with water depths $<200 \mathrm{~m}$ and west of the main flow of the EAC. Chl-a mid-shelf concentrations are about $1-1.5 \mathrm{mg} \cdot \mathrm{m}^{-3}$, and further to the east values decrease to the background value of about $0.2 \mathrm{mg} \cdot \mathrm{m}^{-3}$ and less (Condie and Dunn 2006). The higher Chl-a concentrations tend to be associated with cooler mid-shelf water in all cases, with the SST increasing toward the east and off-shelf. For example, on 16 June 2007, the region of 
high Chl-a extending eastward away from about $153^{\circ} 20^{\prime}$ E and south of $26^{\circ} \mathrm{S}$ is associated with cooler SST of about $22.5^{\circ} \mathrm{C}$; while just to the north of $26^{\circ}$, a Chl-a minimum is associated with SST of more than $24{ }^{\circ} \mathrm{C}$. On 26 July 2008, the mid-shelf water is cool (about $21^{\circ} \mathrm{C}$ ) with higher Chl-a, while further to the east SST warms (the core of the EAC advecting warm Coral Sea water is evident) and Chl-a concentration decreases.

A relationship between cooler SST and higher Chl-a concentration is also frequently evident in P2 events (Figure 5). For example, on 28 September 2002 a P2 event was observed to the southeast of Fraser Island and is associated with SST of about $22^{\circ} \mathrm{C}$, with SST toward the east and west being higher. The same appears to be the situation during other P2 events, e.g. on 15 September 2003, 2 November 2007, 1 December 2008 and 15 October 2009. Thus, there appears to be an indication that upwelling of cooler water from below the surface is a possible driver of elevated P2 Chl-a events.

\subsubsection{Composite event climatology}

Figure 6 represents the average Chl-a (left panels) and SST (right panels) spatial distribution derived from a composite of thirteen events that have been categorised into near-coast mid-shelf (P1) and outer-shelf Southeast Fraser Island blooms (P2) (Table 1). These are all events that were mostly cloud free $(>80 \%)$ in the P1 and P2 regions. The centre of P2 south of Fraser Island is located in the outer-shelf region just to the east of the shelf break (200 
m depth contour) at about $153.5^{\circ} \mathrm{E}$ and $25.6^{\circ} \mathrm{S}$ (Figure 6, lower left panel). The quasi-climatological maximum average estimated Chl-a concentration within the core of $\mathrm{P} 2$ is about $\sim 3 \mathrm{mg} \mathrm{m}^{-3}$. The range of the estimated maximum Chl-a concentration during individual P2 events varies from an estimated minimum of $\sim 0.5 \mathrm{mg} \cdot \mathrm{m}^{-3}$ (weak event, e.g. 2 November 2007, see Figure 5) to an estimated maximum of $\sim 6 \mathrm{mg} \cdot \mathrm{m}^{-3}$ (strong event, e.g. 15 October 2009, see Figure 5). Quasi-climatological SST (Figure 6, top/lower right panels) is about 0.5 to $1{ }^{\circ} \mathrm{C}$ lower within the region characterised by higher Chl-a, and it is noted that the coolest surface water is located in very close proximity to Fraser Island.

Individual outer-shelf Southeast Fraser Island blooms (P2) appear to be reoccurring in the same geographical location, therefore, establishing this distinct outer-shelf quasi-climatological August to December feature to the southeast of Fraser Island. It is noted that the P2 maximum concentration in this average is lower than that of individual sporadic high Chl-a P2 events (see above) due to variability within the P2 distribution and averaging of individual Chl-a maxima.

In contrast, individual near-coast mid-shelf blooms (P1) appear at different locations along the coast, thus leading to a broad quasi-climatological distribution with maximum near-coast concentrations of about $0.5-1 \mathrm{mg} \cdot \mathrm{m}^{-3} \mathrm{in}$ water depth $>40 \mathrm{~m}$ (i.e. mid-shelf) and decreasing toward the continental shelf slope. Both P1 and P2 events appear to be located to the west of the EAC 
core flow with P2 having the higher Chl-a maximum. The elevated inner-shelf Chl-a concentrations in depths shallower than 40 m need to be considered with caution due to likely interference from coastal water turbidity or bottom albedo (see above).

Table 2 provides information about average annual typical conditions, the year-to-year variability, and the overall mean characteristics for both Chl-a blooms. All annual average Chl-a concentrations were above the threshold concentration ranging from about $1.3 \mathrm{mg} \cdot \mathrm{m}^{-3}$ in 2002 to $3.1 \mathrm{mg} \cdot \mathrm{m}^{-3}$ in 2011 for $\mathrm{P} 1$ and from about $1.8 \mathrm{mg} \cdot \mathrm{m}^{-3}$ in 2006 to about $4.1 \mathrm{mg} \cdot \mathrm{m}^{-3}$ in 2002 for P2. The overall quasi-climatological mean is $2.2 \mathrm{mg} \cdot \mathrm{m}^{-3}$ and $3.0 \mathrm{mg} \cdot \mathrm{m}^{-3}$ for the nearcoast mid-shelf (P1) and outer-shelf Fraser Island (P2) blooms. Thus it appears that P2 is generally characterised by a higher Chl-a concentration than P1. This is most likely to the fact that P2 appears to be more localised near the outer-shelf to the southeast of Fraser Island, while P1 occupies a broader midshelf region and locations of P1 maxima vary.

The typical number of events per year with about seven days is similar for both P1 ( 6.5 days) and P2 ( 6.9 days), although significant year-to-year variability is evident (Table 2). It is noted that the period from September to December 2012 was very cloudy, thus only one P2 event was identified. It was also often not possible to clearly identify on-set or termination of an event, which applies to all P1 and P2 events. With this caveat in mind the typical average number of days per year with a characteristic Chl-a event is $\sim 40$ days 
(P1) and $\sim 53$ days (P2). The typical length of an individual event is about 6 days and 8 days for P1 and P2 event respectively.

\subsection{Wind and bottom stress}

The two most likely processes that lead to changes in surface Chl-a concentrations are wind- and current-driven upwelling due to favourable surface and bottom Ekman layer stresses, $\tau_{\mathrm{yb}}$ and $\tau_{\mathrm{yw}}$ respectively. These stresses were discussed in the following sections. The monthly average spatial distribution of bottom layer stress (Figure 7) is obtained from the BRAN3.5 data, and reveals a hot-spot of bottom stress east to south east of Fraser Island. Values are in the order of about $-2 \cdot 5 \cdot 10^{-5} \mathrm{~m}^{2} \cdot \mathrm{s}^{-2}$ to $-3 \cdot 10^{-5} \mathrm{~m}^{2} \cdot \mathrm{s}^{-2}$ at about 25 oS and within the core of the EAC (see Figure 1). While the hot-spot exists throughout the year, the values are lower from April to August, which appears to reflect the seasonal intensification of the EAC flow from about $7 \mathrm{~Sv}$ in winter to about 16 Sv in summer (Ridgway and Godfrey 1997). The important aspect here is that the hot-spot in bottom stress is in proximity to the P2 Chl-a distribution and an accompanying SST minimum discussed above.

A climatological view of daily values for both bottom and wind stress (Figure

8) confirms previous conclusions (see above) that the EAC is likely driving upwelling favourable conditions throughout the year with wind forcing playing a lesser role (Figure 8; note that bottom stress and wind stress as 
computed here differ in physical units since wind stress was scaled by the mean density of air). This applies to the region of interest investigated in this study as well. Bottom boundary layer stress $\tau_{y b}$ varies between an upwelling favourable (i.e. $\tau_{\mathrm{yb}}<0$ ) minimum and maximum stress of about $-8 \cdot 10^{-4} \mathrm{~m}^{2} \cdot \mathrm{s}^{-2}$ and $-2 \cdot 10^{-4} \mathrm{~m}^{2} \cdot \mathrm{s}^{-2}$ during the Southern Hemisphere Spring and early Summer months (the negative sign (-) indicates southward flow). In contrast, upwelling favourable wind stress $\left(\tau_{\mathrm{yw}}<0\right)$ conditions of about $-0.01 \mathrm{~N} \cdot \mathrm{m}^{-2}$ prevail only during the Spring and early Summer period. During the rest of the year, wind unfavourable upwelling conditions $\left(\tau_{\mathrm{yw}}>0\right)$ are dominant. For the 2002-2012 period, the climatological average daily bottom and wind stress data indicate upwelling favourable conditions $86 \%$ (i.e. $\tau_{\mathrm{yb}}<0$ ) and $47 \%$ (i.e. $\tau_{\mathrm{yw}}<0$ ) of the time, while unfavourable conditions occur $14 \%$ (i.e. $\tau_{\mathrm{yb}}>0$ ) and $53 \%$ (i.e. $\tau_{y w}>0$ ) of the time.

The time series of daily averaged wind stress $\tau_{\mathrm{yw}}$, daily and area averaged bottom stress $\tau_{\mathrm{yb}}$ and the occurrence of all 76 P2 events are shown in Figure 9. Most P2 events occur when both $\tau_{\mathrm{yb}}$ and $\tau_{\mathrm{yw}}$ are upwelling favourable (i.e. $\left.\tau_{\mathrm{yb}}<0, \tau_{\mathrm{yw}}<0\right)$. In fact, since the former is upwelling favourable most of the time $(86 \%)$, it appears that favourable wind stress (i.e. $\left.\tau_{\mathrm{yw}}<0\right)$ is likely required to drive a P2 event and unfavourable wind stress (i.e. $\tau_{\mathrm{yw}}>0$ ) is likely to suppress any upwelling leading to P2 distribution. This is summarised in Table 3.

Bottom stress $\tau_{\mathrm{yb}}$ appears to be the key driver of P2 events. A total of $87 \%$ of 
P2 events occur with $\tau_{\mathrm{yb}}<0$ and about $9 \%$ of the P2 events appear to occur with $\tau_{\mathrm{yb}}>0$. The majority of P2 events $(\sim 67 \%)$ occur with both upwelling favourable stresses (i.e. $\tau_{\mathrm{yb}}<0, \tau_{\mathrm{yw}}<0$ ). There are about $8 \%$ of P2 events that occur with favourable wind and unfavourable bottom $\left(\tau_{\mathrm{yw}}<0 ; \tau_{\mathrm{yb}}>0\right)$ or both unfavourable stresses $\left(\tau_{\mathrm{yw}}>0 ; \tau_{\mathrm{yb}}>0\right)$. It should be noted here, that this assessment is considering stresses on the actual days the P2 event is recorded, as shown in Figure 9. Most likely there is a lag involved between forcing and P2 event, and forcing may change while the P2 event is underway. Wind and bottom stress are needed to initiate the surface nutrient layer enrichment process, which is then followed by the Chl-a event; i.e. favourable upwelling conditions could exist before the actual Chl-a event occurs and this condition could at the time of the event.

\section{Discussion}

The prevalence of sporadic high Chl-a events along shelf off the southeast coast of Queensland, near Fraser Island, and the possible physical drivers was investigated. This region is where the EAC accelerates its southward flow, narrows, and closely follows the continental shelf. High Chl-a concentration events in shelf waters are usually attributed to wind- and current-driven upwelling processes. In this paper, the analysis of IMOS provided data for the period 2002-2012 leads to the categorisation of the observed Chl-a concentration estimates into two distinct quasi-climatological distributions. These are referred to as near-coast mid-shelf blooms and outer-shelf Fraser 
Island blooms, or P1 and P2 events respectively. The patterns are always located in mid-to outer-shelf waters and to the west of the EAC core, as established from IMOS SST data. P1 occurred primarily during the March to August (Southern Hemisphere Spring to Winter) period, and P2 dominated during the August to December months (see Figure 3). P2 Chl-a maxima appeared to be higher than those of P1 events.

We aimed, in the first instance, to document the frequency and distribution of sporadic high Chl-a events (i.e. P2) on the outer-shelf near Fraser Island. This expands on other previous studies including Oke and Middleton (2001), Everett et al. (2014), and Rossi et al. (2014) that focused on the Australian southeast coast and those that focused on the Great Barrier Reef Region (e.g. Mao and Luick 2014). The study site was previously identified as a key Australian marine ecological site (Middleton et al., 1994; Young et al., 2011; Dambacher et al., 2012). Therefore, of particular interest here are the Southeast Fraser Island blooms (P2) and the processes that possibly drive these sporadic events. It was found that about $87 \%$ of all of these events occur with upwelling favourable bottom stress, and about $67 \%$ of those events are also characterised by upwelling favourable northerly winds. It is the combination of upwelling favourable wind and bottom stress that generated most of the P2 events, but bottom stress is the main driver of these events. No P2 event occurred with upwelling unfavourable bottom layer stress (Table 3), and it is argued that bottom layer stress is thus the main driver of P2 upwelling events. Wind stress is likely to enhance or suppress the bottom 
stress generated upwelling process. A wind-stress cut-off definition of $\tau_{\mathrm{yw}}<0$ $\mathrm{N} \cdot \mathrm{m}^{-2}$ and $\tau_{\mathrm{yw}}>0 \mathrm{~N} \cdot \mathrm{m}^{-2}$ is used in this assessment. Wood et al. (2012) derived a cut-off or threshold value of about $\tau_{\mathrm{yw}}<-0.042 \mathrm{~N} \cdot \mathrm{m}^{-2}$ for several locations along the southeast coast of Australia, and Everett et al. (2014) used this value to assess the role of wind-stress driven upwelling processes along the east Australian coast between about $28^{\circ} \mathrm{S}$ and $37^{\circ} \mathrm{S}$. Using a threshold value similar to Everett et al. (2014) would further shift the analysis presented here in support of the argument that P2 upwelling events near Fraser Island are driven principally by bottom-shear stress rather than surface layer wind stress.

Using historical satellite-sensed SST and SSH data, Rossi et al. (2014) found both wind-driven and current-driven favourable upwelling conditions for the period from about September to December for this region. This is consistent with the Sandy Cape wind stress data (Figure 8) used here, and indicates that the northerly component intensifies during this period. It coincides with an intensification of the EAC in spring, leading to an increased bottom layer stress and more favourable upwelling conditions (Figure 7). The September to December period is one when P2 is frequently observed (see Figure 3), thus lending strong support to the conclusion that both favourable wind- and current-driven upwelling conditions are working in unison to drive frequent episodic P2 high Chl-a events. It was also found that $67 \%$ of all P2 events occurred during the spring and early summer when bottom stress is at a maximum and upwelling favourable winds with a strong northerly 
component occur. This is consistent with previous assessments of drivers of upwelling along regions further south (e.g. Thompson et al., 2011), which all argue for a significant role of the EAC in driving upwelling, and confirms speculation of current driven upwelling in the region of interest (e.g. Middleton et al., 1994).

Wind- and current driven upwelling are only two of several processes that can lead to surface layer nutrient enrichment as a precursor to high Chl-a events or blooms. Other nutrient enrichment processes include high river runoff from coastal catchments and tidal flushing of high nutrient water away from shallow coastal areas. The study site is characterised by a variable subtropical climate. River run-off and rainfall and nutrient transport from catchments into the coastal ocean would be high during the wetter subtropical spring and summer months, possibly contributing to establishing P1 events. It is interesting to note that during the high run-off period of the year, P1 events appear to be less developed, while P2 is fully established (Figure 2). Satellite chlorophyll-a data are unreliable in coastal oceans due to influences of dissolved organic matter and sediment. This is potentially critical in the vicinity of the Mary River, which discharges into the southern parts of Hervey Bay (Figure 1). Phytoplankton blooms and near-coast (i.e. inner-shelf) Chl-a concentration maxima are possible during periods of high river run-off. Previous analysis of three extreme river discharge events in the Hervey Bay region found that the freshwater plume-impacted coastal zone of 
the inner-shelf extends only a few kilometres from the coast (Gräwe et al., 2010). Water depth is well below the $40 \mathrm{~m}$ threshold previously introduced.

The influence of the river-plume was also discerned from Chl-a imagery following the significant rainfall and river run-off events during the December 2010 to January 2011 period (not shown here). Chl-a concentration maxima well above $5 \mathrm{mg} \cdot \mathrm{m}^{-3}$ were evident in the near coast zone of Hervey Bay within in the Great Sandy Strait, and just to the south of Fraser Island (see Figure 1), but all well within water shallower than $40 \mathrm{~m}$ (i.e. the inner-shelf). Therefore, the impact of Mary River water and phytoplankton blooms on the mid-shelf P1 Chl-a concentration is considered possible, albeit very limited, while any influence on the outer-shelf P2 Chl-a concentration is very unlikely. In contrast, Chl-a concentration maxima in the inner-shelf region are likely to be driven or contributed to by river discharges and associated nutrient and sediment from land sources. For example, Brodie et al. (2010) found significantly elevated inner-shelf Chl-a concentrations following flood events. This lends confidence to the analysis, the identified pattern, and the proposed mechanisms presented here, in particular in regards to P2. However, future analysis of the near-shore dynamics is needed to discern the local dynamics, spread of river-originating dissolved matter, sediments, subsequent phytoplankton blooms and the influence on P1 and P2 Chl-a events.

Further, current-driven upwelling considered in this study is a net effect of the ocean's circulation; i.e. it is an integral of current intensification, 
variability, and reversal, mesoscale eddies and shelf encroachment, see e.g. Rossi et al. (2014). The contribution of individual processes to the net flow is not considered here, and is subject to future investigations. This includes in particular the role of mesoscale eddies that have also been shown to promote upwelling (and downwelling) and the flux of nutrients into the surface (e.g. Weeks et al. 2010; Young et al. 2011).

In-situ observations from the study site are limited. Middleton et al (1994) observed temperature, salinity, and nutrients along a cross-shelf section that intersects with the location of $\mathrm{P} 2$ and hypothesized that the EAC may drive nutrient-rich water to the shelf, but do not investigate this physical mechanism further. Young et al (2011) reported measurements of Chl-a, nutrients (nitrate, phosphate) and other hydrographic parameters sampled to the east of the shelf break and at the outer-shelf location of $\mathrm{P} 2$, and otherwise relied on additional information from satellite imagery. They concluded that sub-surface cold-core eddy activity near Fraser Island at about $154^{\circ} \mathrm{E}$ and $25^{\circ}$ $30^{\circ} \mathrm{S}$ and topographically induced mixing could explain elevated Chl-a concentrations. Both locations are to the east of P2. Since in-situ observations from the study site are sparse, the analysis reported here could potentially guide the planning of a future multi-disciplinary field survey to further investigate all the physical factors that establish an important marine ecological region and fisheries along the east coast of Australia.

In the future, the circulation of shelf water and its contribution to maintaining 
and disbursing high Chl-a events is to be considered as well. Intermittent eddy activity and upwelling is also induced and modified by topography features (e.g. Young et al., 2011; Kämpf, 2012). The propagation of coastal trapped waves (e.g. in Andrews and Gentien, 1982; Roughan and Middleton, 2004) was not considered here in further detail. However, this is another upwelling driving process that may contribute particularly to explaining the generation of inner-to-mid-shelf P1 events. Future analysis of sea surface height data could be utilised to investigate wave propagation and also to identify EAC coastal encroachment leading to periods of high bottom shear stress.

\section{Conclusion}

The outer-shelf subtropical waters south of Fraser Island were previously identified as a key eastern marine ecological region. This analysis found that this site is characterised by re-occurring high Chl-a events during the Southern Hemisphere Spring and Summer months. The EAC flow intensifies during this period. The associated bottom stress was identified as the main driver of upwelling and sporadic high Chl-a events. Wind stress played a secondary role. Five to six Southeast Fraser Island blooms (P2) events occurred on average per year with each one lasting for about seven days. Chla maxima were well above the background value, coincided with the location of negative SST anomalies and appeared not to be influenced by river discharges. However, this initial analysis establishes the EAC driven bottom 
stress as a key driver of a marine ecological hot-spot, an important eastern fisheries and the "Southeast Fraser Island Upwelling System". Future work is required to investigate the regional shelf circulation, assess the contribution of eddies, study the advection of Chl-a filaments and potential uplift of subsurface Chl-a maxima, and to probe the influence of local bathymetry on upwelling events.

\section{Acknowledgment}

We would like to thank the Integrated Marine Observing System (IMOS) and the Bluelink teams for providing data in support of this research. Mr Daniel Brieva is thankful for a Chilean Government scholarship. We also would like to thank four anonymous reviewers and their comments, which greatly assist us in finalising our paper.

\section{References}

Aguiar, A. L., Cirano, M., Pereira, J., and Marta-Almeida, M. 2014. Upwelling processes along a western boundary current in the Abrolhos-Campos region of Brazil. Continental Shelf Research 85, 42-59.

Andrews, J. C. and Gentien, P. 1982. Upwelling as a Source of Nutrients for the Great Barrier Reef Ecosystems: A Solution to Darwin's Question? Marine Ecology Progress Series 8, 257-269. 
Armbrecht, L., Roughan, M., Rossi, V., Schaeffer, A., Davies, P. L., Waite, A. M., and Armand, L. K. 2014. Phytoplankton composition under contrasting oceanographic conditions: Upwelling and downwelling (Eastern Australia). Continental Shelf Research 75, 54-67.

Aryal, R., Kandel, D., Acharya, D., Chong, M. N., and Beecham, S. 2012. Unusual Sydney dust storm and its mineralogical and organic characteristics. Environmental Chemistry 9, 537-546.

Brodie, J., Schroeder, T., Rohde, K., Faithful, B. M., Dekker, A., Brando, V., and Maughan, M., 2010. Dispersal of suspended sediments and nutrients in the Great Barrier Reef lagoon during river-discharge events: conclusions from satellite remote sensing and concurrent flood-plume sampling. Marine and Freshwater Research 61, 651-664.

Cannizzaro, J.P. \& Carder, K.L., 2006. Estimating chlorophyll a concentrations from remote-sensing reflectance in optically shallow waters. Remote Sensing of Environment 101, 13-24.

Condie, S. A. and Dunn, J. R. 2006. Seasonal characteristics of the surface mixed layer in the Australasian region: implications for primary production regimes and biogeography. Marine and Freshwater Research 57, 569-590. 
Dambacher, J. M., Hosack, G. R., and Rochester, W. A. 2012. Ecological Indicators for the Exclusive Economic Zone of Australia's East Marine Region. A report prepared for the Australian Government Department of Sustainability, Environment, Water, Population and Communities. CSIRO Wealth from Oceans Flagship, Hobart.

Echevin, V., O. Aumont, O, Ledesma, J., and Flores, G. 2008. The seasonal cycle of surface chlorophyll in the Peruvian upwelling system: A modelling study. Progress In Oceanography 79, 167-176.

Everett, J. D., Baird, M. E., Moninya, R., Suthers, I. M., and Doblin, M. A. 2014. Relative impact of seasonal and oceanographic drivers on surface chlorophyll a along a Western Boundary Current. Progress In Oceanography 120, 340-351.

Gabric, A.J., Cropp, R.A., McTainsh, G.H., Johnston, B.M., Butler, H., Tilbrook, B., and Keywood, M. 2010. Australian dust storms in 2002-2003 and their impact on Southern Ocean biogeochemistry. Global Biogeochemial Cycles 24, GB2005.

Gräwe, U., Wolff, J.-O., Ribbe, J., 2010. Impact of Climate Variability on an East Australian Bay. Estuarine Coastal Shelf Science 86, 247-257. 
Griffin, D. A., Middleton, J. H. and Bode, L. 1987. The tidal and longer-period circulation of Capricornia, Southern Great Barrier Reef. Marine and Freshwater Research 38, 461-474.

Hallegraeff, G. M. and Jeffrey, S. W. 1993. Annually recurrent diatom blooms in spring along the New South Wales coast of Australia. Marine and Freshwater Research 44, 325-334.

Hanson, C. E., Pattiaratchi, C. B., and Waite, A. M. 2005. Sporadic upwelling on a downwelling coast: Phytoplankton responses to spatially variable nutrient dynamics off the Gascoyne region of Western Australia. Continental Shelf Research 25, 1561-1582.

IMOS, 2013. Chlorophyll-a and Sea Surface Temperature data. http://aodaac1-mel.vic.csiro.au:8080/thredds/catalog/imossrs/oc/modis/aust.day/catalog.html. Accessed 16/8/2013.

Kämpf, J., 2012. Lee effects of localized upwelling in a shelf-break canyon. Continental Shelf Research 42, 78-88.

Kämpf, J., 2014. Phytoplankton blooms on the western shelf of Tasmania: evidence of a highly productive ecosystem. Ocean Science Discussion 11, 2172-2204. 
Kämpf, J., Doubell, M, Griffin, D., Matthews, R. L., and Ward, T. M. 2004.

Evidence of a large seasonal coastal upwelling system along the southern shelf of Australia. Geophysical Research Letters 31, doi:10.1029/2003GL019221.

Kowalik, Z. and Murty, T. S. 1993. Numerical Modeling of Ocean Dynamics. Advanced Series on Ocean Engineering. World Scientific.

Lewis, R. K. , 1981. Seasonal Upwelling along the South-eastern Coastline of South Australia. Australian Journal of Marine and Freshwater Research 32, 843-854.

Mao, Y., Luick, J. L. 2014. Circulation in the southern Great Barrier Reef studied through an integration of multiple remote sensing and in situ measurements. Journal of Geophysical Research-Oceans 119, 1621-1643.

McClatchie, S., J. F. Middleton, J. F., and Ward, T. M. 2006. Water mass analysis and alongshore variation in upwelling intensity in the eastern Great Australian Bight. Journal of Geophysical Research - Oceans 111, C08007.

Middleton, J. H., Coutis, P., Griffin, D. A., Macks, A., McTaggart, A., Merrifield, M. A., and Nippard, G. J. 1994. Circulation and water mass characteristics of the southern Great Barrier Reef. Marine and Freshwater Research 45, 1-18. 
Middleton, J. H., Arthur, G., van Ruth, P., Ward, T. M., McClean, J. L., Maltrud, M. E., Gill, P., Levings, A., and Middleton, S. 2007. El Nino Effects and Upwelling off South Australia. Journal of Physical Oceanography 37, 2458-2477.

Middleton, J. F., James, N. P., James, C., and Bone, Y. 2014. Cross-shelf seawater exchange controls the distribution of temperature, salinity, and neritic carbonate sediments in the Great Australian Bight. Journal of Geophysical Research - Oceans 2539-2549.

Moses, W. J., A. A. Gitelson, Perk, R. L., Gurlin, D., Rundquist, D. C., Leavitt, B. C., Barrow, T. M., and Brakhage, P. 2012. Estimation of chlorophyll-a concentration in turbid productive waters using airborne hyperspectral data. Water Research 46, 993-1004.

Murphy, B. F., and Ribbe, J. 2004. Variability of southeast Queensland rainfall and its predictors. International Journal of Climatology 24, 703-721.

Nieblas, A.-E., Sloyan, B. M., Hobday, A. J., Coleman, R., and Richardson, A. J. 2009. Variability of biological production in low wind-forced regional upwelling systems: A case study off southeastern Australia. Limnology and Oceanography 54, 1548-1558. 
Oke, P. R. and Middleton, J. H. 2000. Topographically Induced Upwelling off Eastern Australia. Journal of Physical Oceanography 30, 512-531.

Oke, P. R. and Middleton, J. H. 2001. Nutrient enrichment off Port Stephens: the role of the East Australian Current. Continental Shelf Research 21, 587606.

Oke, P. R., Brassington, G. B., Griffin, D. A., and Schiller, A. 2008. The Bluelink ocean data assimilation system (BODAS). Ocean Modelling 21, 4670.

O'Reilly, J.E., and 24 Coauthors, 2000: SeaWiFS Postlaunch Calibration and Validation Analyses, Part 3. NASA Tech. Memo. 2000-206892, Vol. 11, S.B. Hooker and E.R. Firestone, Eds., NASA Goddard Space Flight Center, 49 pp.

Pearce, A. F., Lynch, M. J., and Hanson, C. E. 2006. The Hillarys Transect (1): Seasonal and cross-shelf variability of physical and chemical water properties off Perth, Western Australia, 1996-98. Continental Shelf Research 26, 16891729.

Rennie, S. J., Pattiaratchi, C. B., and McCauley, R. D. 2009. Numerical simulation of the circulation within the Perth Submarine Canyon, Western Australia. Continental Shelf Research 29, 2020-2036. 
Ribbe, J. 2006. A study into the export of saline water from Hervey Bay, Australia. Estuarine, Coastal and Shelf Science 66, 550-558.

Ridgway, K. R. and Godfrey, J. S. 1997. Seasonal cycle of the East Australian Current. Journal of Geophysical Research - Oceans 102, 22921-22936.

Rossi, V., Feng, M., Pattiaratchi, C., Roughan, M., and Waite, A. M. 2013. On the factors influencing the development of sporadic upwelling in the Leeuwin Current system. Journal of Geophysical Research - Oceans 118, 3608-3621.

Rossi, V., Schaeffer, A., Wood, J., Galibert, G., Morris, B., Sudre, J., Roughan, M., and Waite, A. M. 2014. Seasonality of sporadic physical processes driving temperature and nutrient high-frequency variability in the coastal ocean off southeast Australia. Journal of Geophysical Research - Oceans 119, 445-460.

Roughan, M. and Middleton, J. H. 2002. A comparison of observed upwelling mechanisms off the east coast of Australia. Continental Shelf Research 22, $2551-2572$.

Roughan, M. and Middleton, J. H. 2004. On the East Australian Current: Variability, encroachment, and upwelling. Journal of Geophysical Research 109, C07003, doi:10.1029/2003JC001833. 
Schaeffer, A., Roughan, M., and Morris, B. D. 2013. Cross-Shelf Dynamics in a Western Boundary Current Regime: Implications for Upwelling. Journal of Physical Oceanography 43, 1042-1059.

Schaeffer, A., Roughan, M., Wood, J.E. 2014. Observed bottom boundary layer transport and uplift on the continental shelf adjacent to a western boundary current. Journal of Geophysical Research - Oceans 119, 4922-4939.

Suthers, I. M., J. W. Young, et al. 2011. The strengthening East Australian Current, its eddies and biological effects - an introduction and overview. Deep Sea Research Part II: Topical Studies in Oceanography 58 538-546.

Thompson, P. A., Bonham, P. B., Waite, A. M., Clementson, L. A., Cherukuru, N., and Doblin, M. A., 2011. Contrasting oceanographic conditions and phytoplankton communities on the east and west coasts of Australia, Deep Sea Research Part II 58, 645-663.

Ward, T. M., McLeay, L. J., Dimmlich, W., F., Rogers, P. J., McClatchie, S., Matthews, R., Kämpf, J., and van Ruth, P. D. 2006. Pelagic ecology of a northern boundary current system: effects of upwelling on the production and distribution of sardine (Sardinops sagax), anchovy (Engraulis australis) and southern bluefin tuna (Thunnus maccoyii) in the Great Australian Bight. Fisheries Oceanography 15, 191-207. 
Weeks, S. J., Bakun, A., Steinberg, C. R., Brinkman, R., and Hoegh-Guldberg, O., 2010, The Capricorn Eddy: a prominent driver of the ecology and future of the southern Great Barrier Reef. Coral Reefs 29, 975-985.

Wood, J. E., Roughan, M., and Tate, P. M. 2012. Finding a proxy for wind stress over the coastal ocean. Marine and Freshwater Research 63, 528-544.

Xu, J., Lowe, R. J., Ivey, G. N., Pattiaratchi, C., Jones, N. L., and Brinkman, R. 2013. Dynamics of the summer shelf circulation and transient upwelling off Ningaloo Reef, Western Australia. Journal of Geophysical Research - Oceans $118,1099-1125$.

Young, J. W., Hobday, A. J., Campbell, R. A., Kloser, R. J., Bonham, P. I., Clementson, L. A., and Lansdell, M. J. 2011. The biological oceanography of the East Australian Current and surrounding waters in relation to tuna and billfish catches of eastern Australia. Deep-Sea Research II 58, 720-733.

Zhang, R.-H., Chen, D., and Wang, G. 2011. Using Satellite Ocean Color Data to Derive an Empirical Model for the Penetration Depth of Solar Radiation (Hp) in the Tropical Pacific Ocean. Journal of Atmospheric and Oceanic Technology 28, 944-965. 


\section{Tables:}

Table 1: Statistics of Satellite Image Analysis

\begin{tabular}{|l|l|}
\hline Period & $9 / 8 / 2002$ to $31 / 12 / 2012$ \\
\hline Total images & 3729 \\
\hline Pattern 1 (P1) events: & 67 events or 436 days in total \\
\hline Pattern 2 (P2) events & 76 events or 585 days in total \\
\hline
\end{tabular}


Table 2: Year-to year and mean characteristics of P1 and P2 events

\begin{tabular}{|c|cc|cc|cc|cc|}
\hline Year & \multicolumn{2}{|c|}{ Total Days } & \multicolumn{2}{c|}{ No of Events } & \multicolumn{2}{c|}{ Event Days } & \multicolumn{2}{c|}{ Chl-a $\left(\mathbf{m g} \mathbf{m}^{\mathbf{3}}\right.$ ) } \\
& P1 & P2 & P1 & P2 & P1 & P2 & P1 & P2 \\
\hline 2002 & 11 & 57 & 3 & 5 & 3.7 & 11.4 & $1.3 \pm 0.0$ & $4.1 \pm 2.6$ \\
\hline 2003 & 25 & 50 & 6 & 10 & 4.2 & 5.0 & $2.2 \pm 1.9$ & $4.0 \pm 2.5$ \\
\hline 2004 & 33 & 59 & 5 & 10 & 6.6 & 5.9 & $1.8 \pm 0.7$ & $2.6 \pm 1.5$ \\
\hline 2005 & 51 & 57 & 11 & 6 & 4.6 & 9.5 & $1.3 \pm 0.5$ & $2.9 \pm 2.2$ \\
\hline 2006 & 29 & 57 & 5 & 7 & 5.8 & 8.1 & $2.3 \pm 0.8$ & $1.8 \pm 0.6$ \\
\hline 2007 & 64 & 85 & 5 & 6 & 12.8 & 14.2 & $2.6 \pm 1.9$ & $2.5 \pm 1.8$ \\
\hline 2008 & 59 & 42 & 10 & 7 & 5.9 & 6.0 & $2.2 \pm 1.2$ & $2.5 \pm 1.3$ \\
\hline 2009 & 30 & 86 & 6 & 12 & 5.0 & 7.2 & $3.0 \pm 1.9$ & $3.3 \pm 1.9$ \\
\hline 2010 & 15 & 26 & 5 & 6 & 3.0 & 4.3 & $1.7 \pm 0.5$ & $2.9 \pm 1.8$ \\
\hline 2011 & 70 & 57 & 10 & 6 & 7.0 & 9.5 & $3.1 \pm 1.6$ & $1.9 \pm 2.0$ \\
\hline 2012 & 49 & 9 & 5 & 1 & 9.8 & 9.0 & $2.9 \pm 0.7$ & $4.0 \pm 0.0$ \\
\hline Mean & $\mathbf{3 9 . 6}$ & $\mathbf{5 3 . 2}$ & $\mathbf{6 . 5}$ & $\mathbf{6 . 9}$ & $\mathbf{6 . 1}$ & $\mathbf{7 . 7}$ & $\mathbf{2 . 2}$ & $\mathbf{3 . 0}$ \\
\hline \hline
\end{tabular}


Table 3: Assessment of Upwelling Favourable Conditions for the Southeast Fraser Island Bloom (P2 events)

\begin{tabular}{|c|c|}
\hline Stresses & {$[\%]$} \\
\hline$\tau_{\mathrm{yb}}<0$ and $\tau_{\mathrm{yw}}<0$ & 59.2 \\
\hline$\tau_{\mathrm{yb}}<0$ and $\tau_{\mathrm{yw}}>0$ & 28.4 \\
\hline$\tau_{\mathrm{yb}}>0$ and $\tau_{\mathrm{yw}}<0$ & 1.4 \\
\hline$\tau_{\mathrm{yb}}>0$ and $\tau_{\mathrm{yw}}>0$ & 7.0 \\
\hline
\end{tabular}

"Note: The gap in daily wind data covers about 4.1\% of the period 2002-2012. 


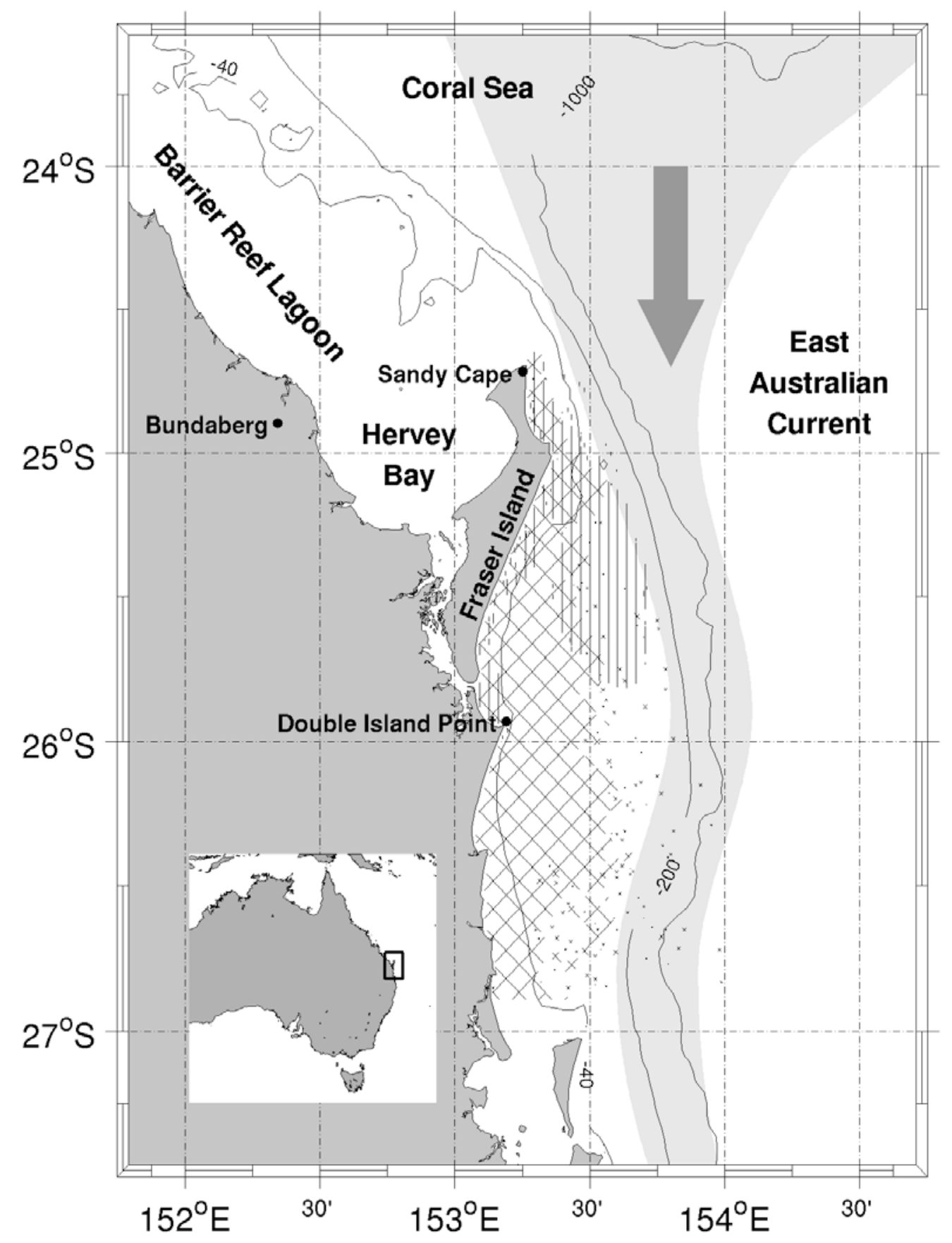

Figure 1: Map of the region of interest along the central east coast of Australia. The most prominent feature here is the East Australian Current (EAC) moving warm northern Coral Sea Water southward. Episodic high Chl-a concentrations are found to the south and southeast of Fraser Island and are discussed in this paper. These are in the text referred to as near-coast midshelf (P1, cross-pattern) and Southeast Fraser Island blooms (P2, vertical lines). Indicated is the $40 \mathrm{~m}$ depth contour with coincides with the approximate depth of light penetration 


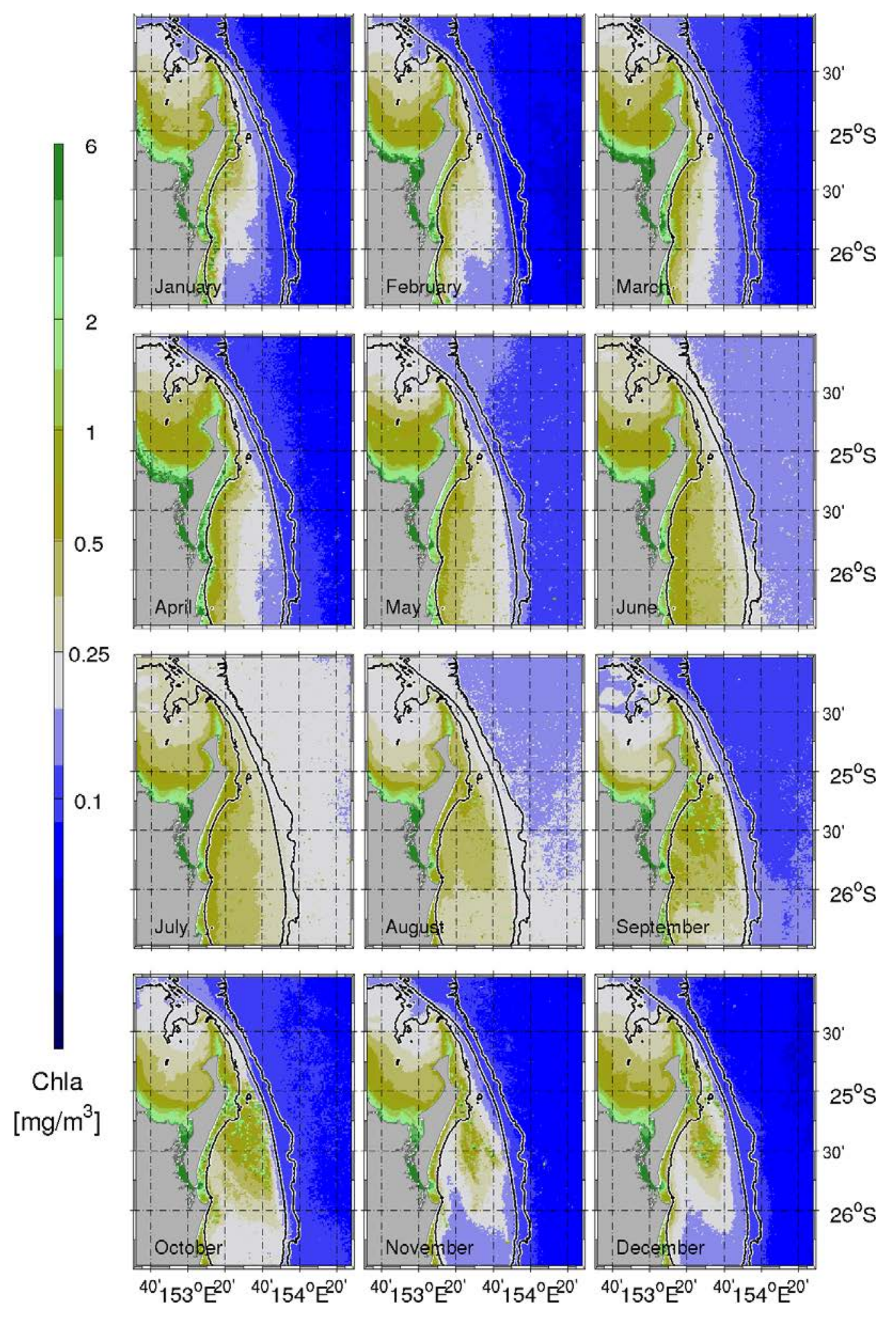

Figure 2: Mean monthly January (top left panel) to December (bottom right panel) climatological Chl-a distribution $\left(\mathrm{mg}^{-3} \mathrm{~m}^{-3}\right.$ ) for the period 2002-2012. Data source: IMOS (2013). 
Pattern 1

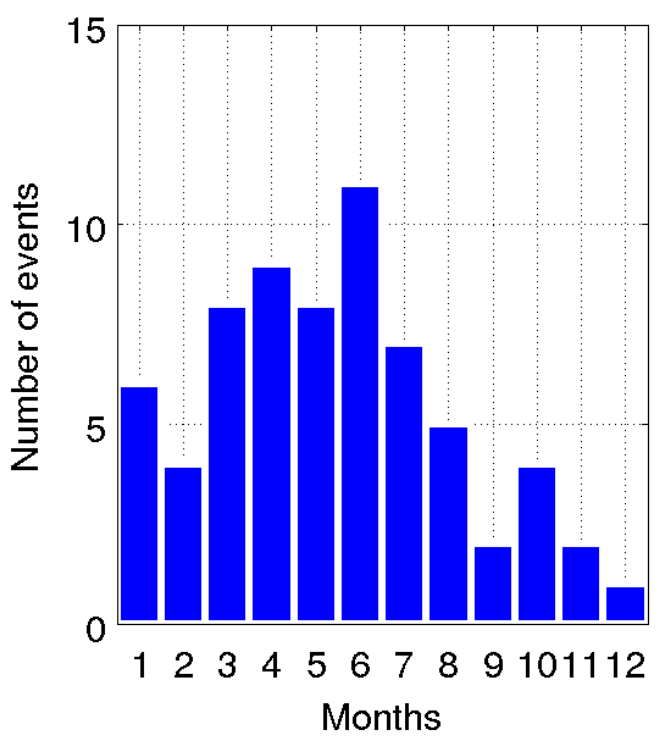

Pattern 2

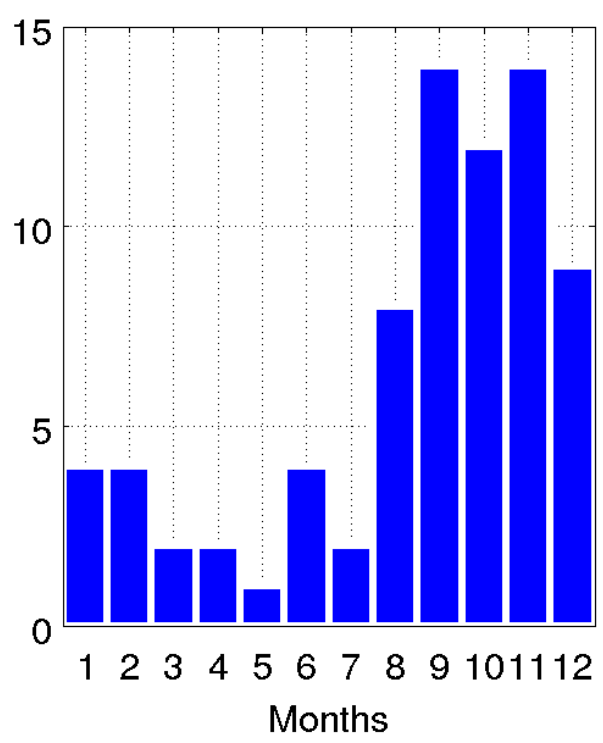

Figure 3: Frequency or number of identified events with near-coast mid-shelf (P1, left panel) and southeast Fraser Island (P2, right panel) distributions. Data source: IMOS (2013). 

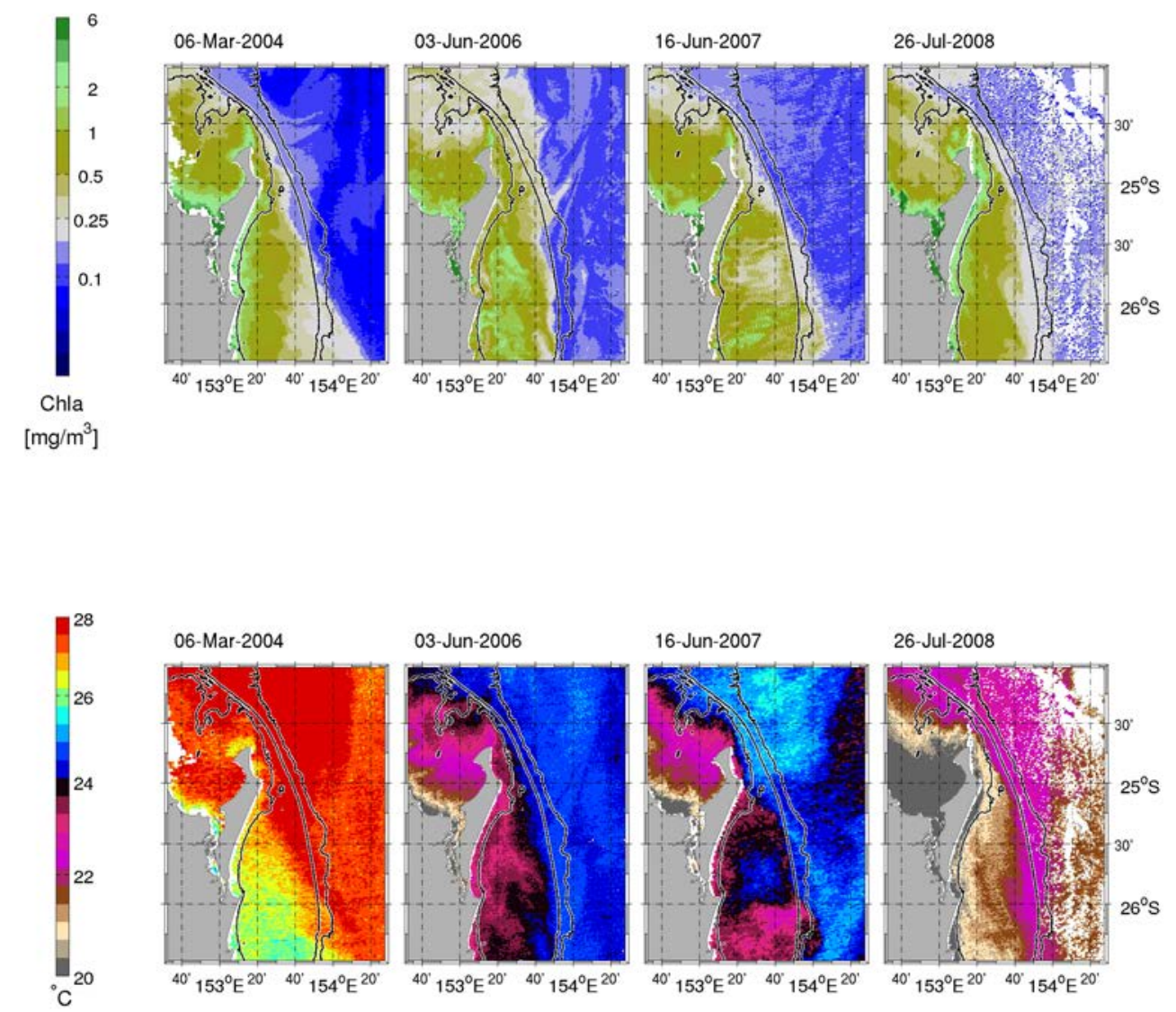

Figure 4: Series of high Chl-a $\left(\mathrm{mg} \cdot \mathrm{m}^{-3}\right)$ events (top panel) as examples for typical near-coast mid-shelf blooms (P1 events) occurring primarily during the period March to July, lower panel shows SST $\left({ }^{\circ} \mathrm{C}\right)$; from left to right distributions on a) March 6, 2004; June 3, 2002; June 16, 2007, and July 26, 2008; 

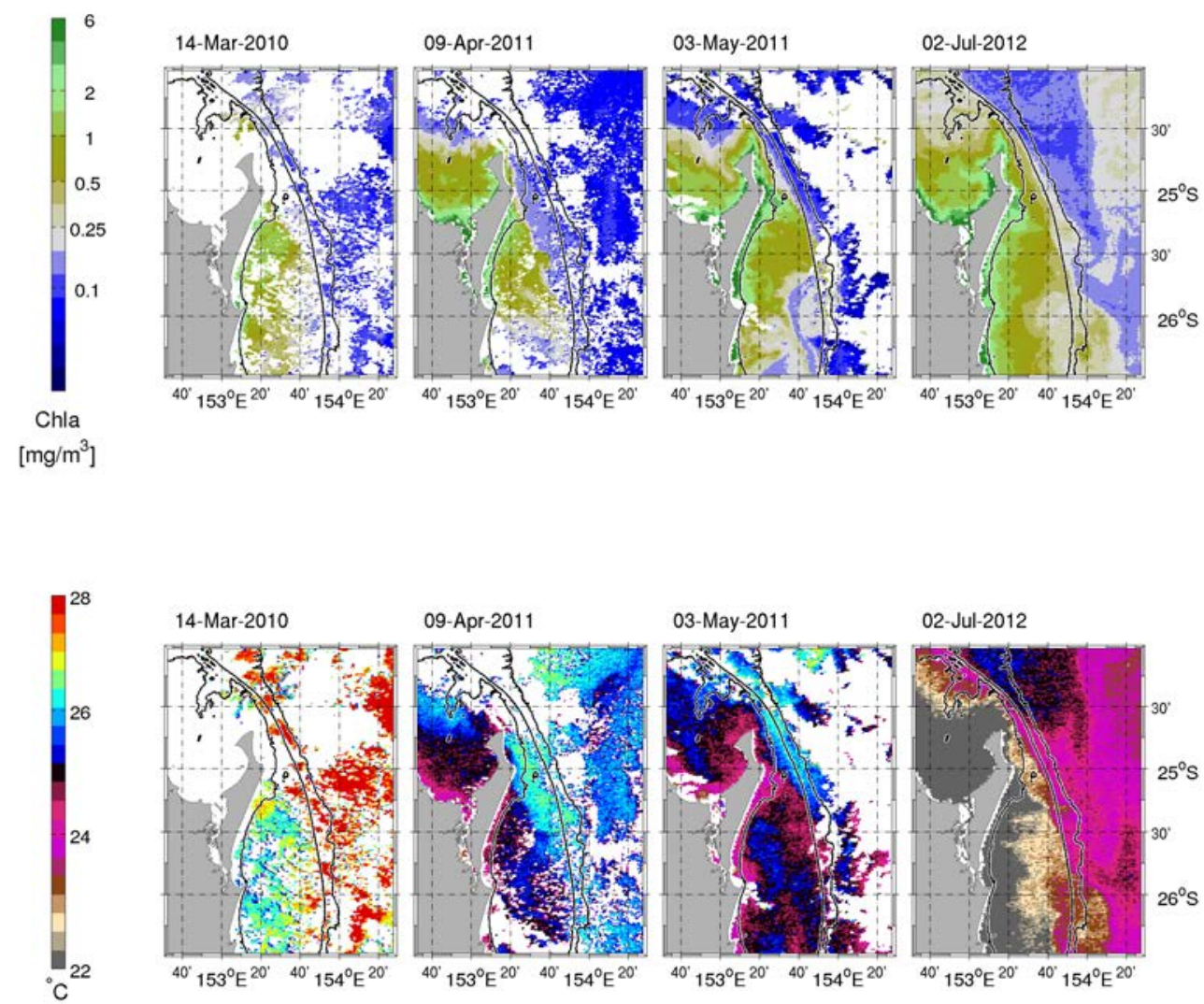

09-Apr-2011

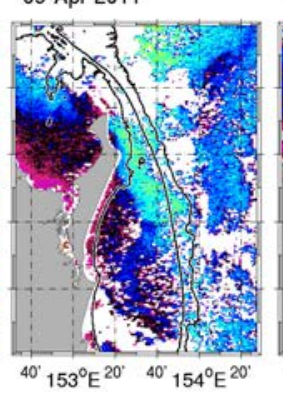

03-May-2011

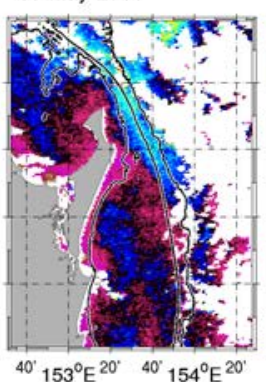

02-Jul-2012

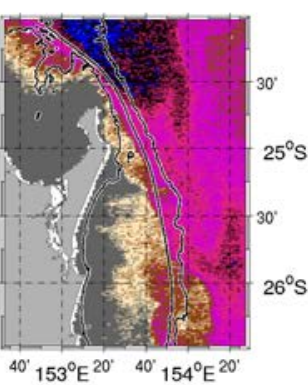

b) March 14, 2010; April 9, 2011; May 3, 2011 and July 2, 2012. White areas are due to clouds and land, b) March 14, 2010; April 9, 2011; May 3, 2011 and July 2, 2012. Data source: IMOS (2013). 

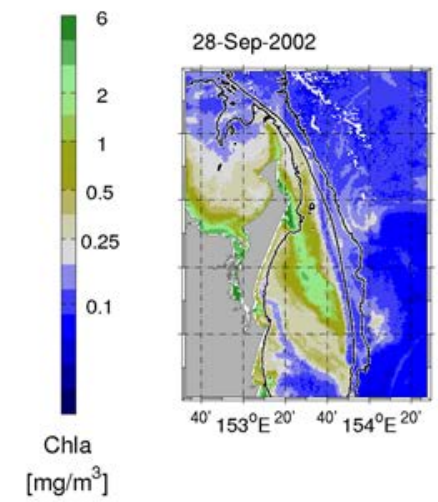

15-Sep-2003
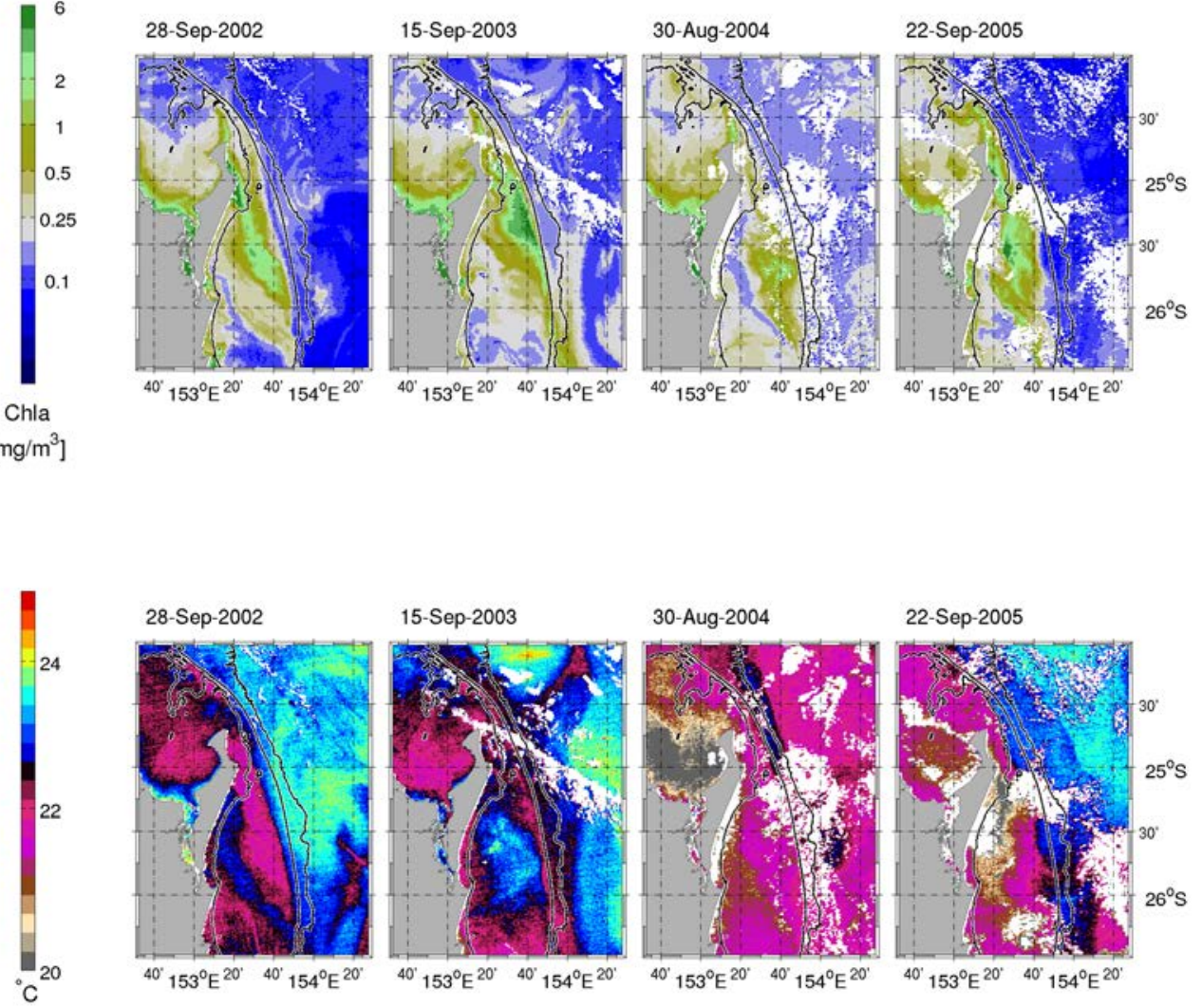

Figure 5: Series of high Chl-a $\left(\mathrm{mg} \cdot \mathrm{m}^{-3}\right)$ events as examples for typical southeast Fraser Island blooms (P2 events) occurring primarily during the period August to February, lower panel shows SST $\left({ }^{\circ} \mathrm{C}\right)$; from left to right distributions on a) September 28, 2002; September 13, 2003; August 30, 2004, and September 22, 2005; 

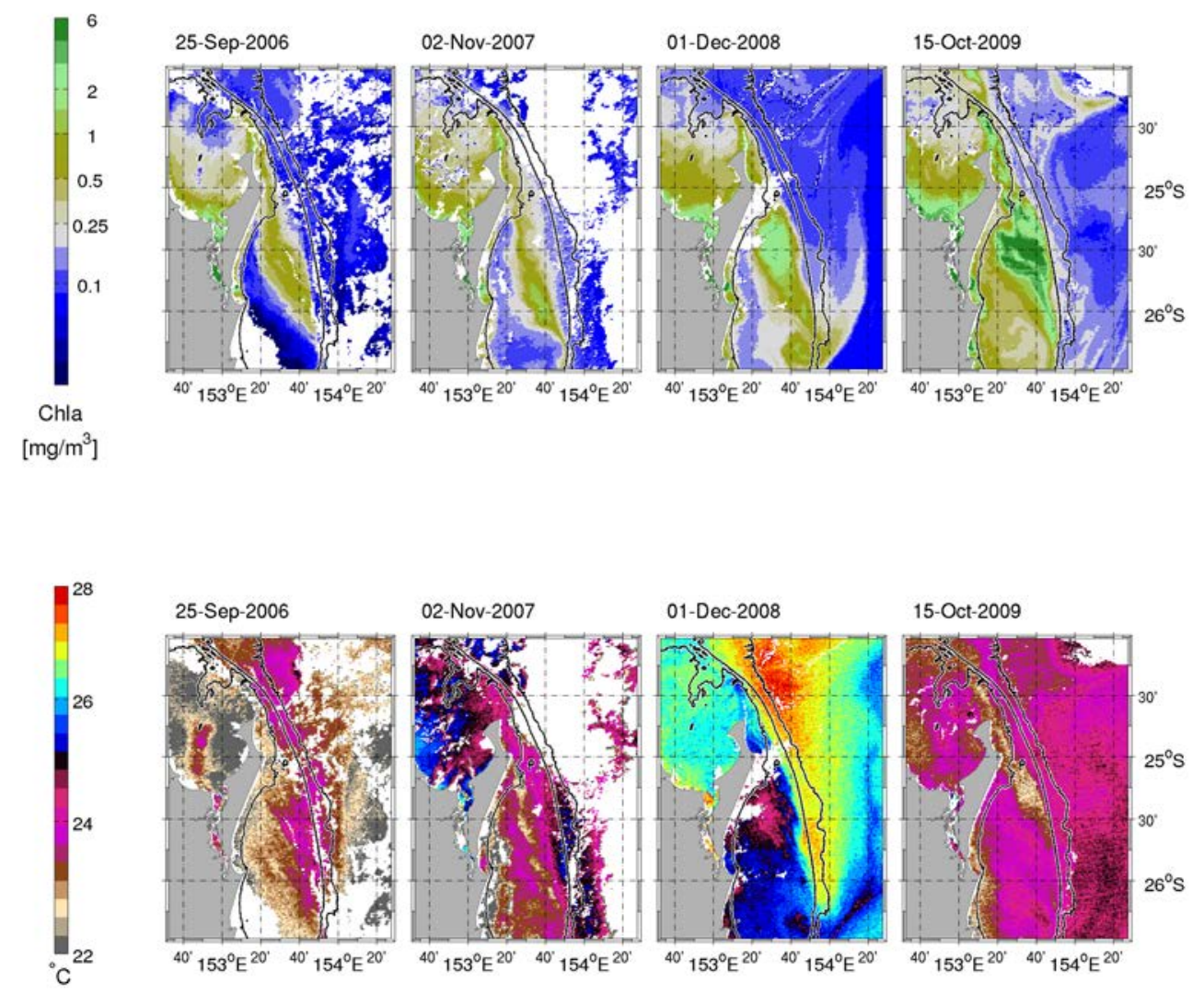

b) September 25, 2006; November 2, 2007, December 1, 2008, and October 15, 2009. Data source: IMOS (2013). 

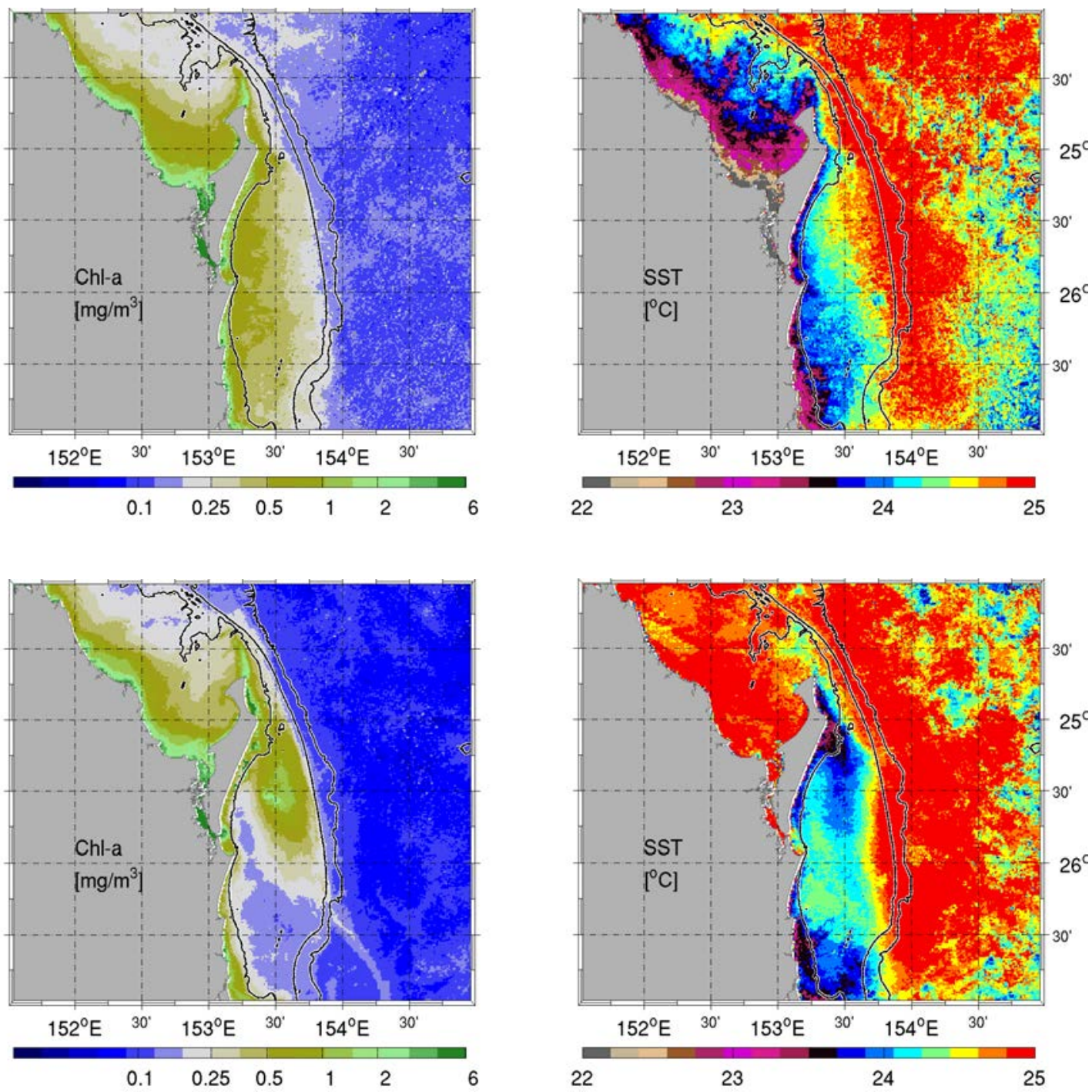

Figure 6: Quasi-climatological Chl-a $\left(\mathrm{mg}^{-3}\right)$ and SST $\left({ }^{\circ} \mathrm{C}\right)$ distributions for near-coast mid-shelf (P1, top panels) and Southeast Fraser Island (P2, lower panels) blooms. Data source: IMOS (2013). 

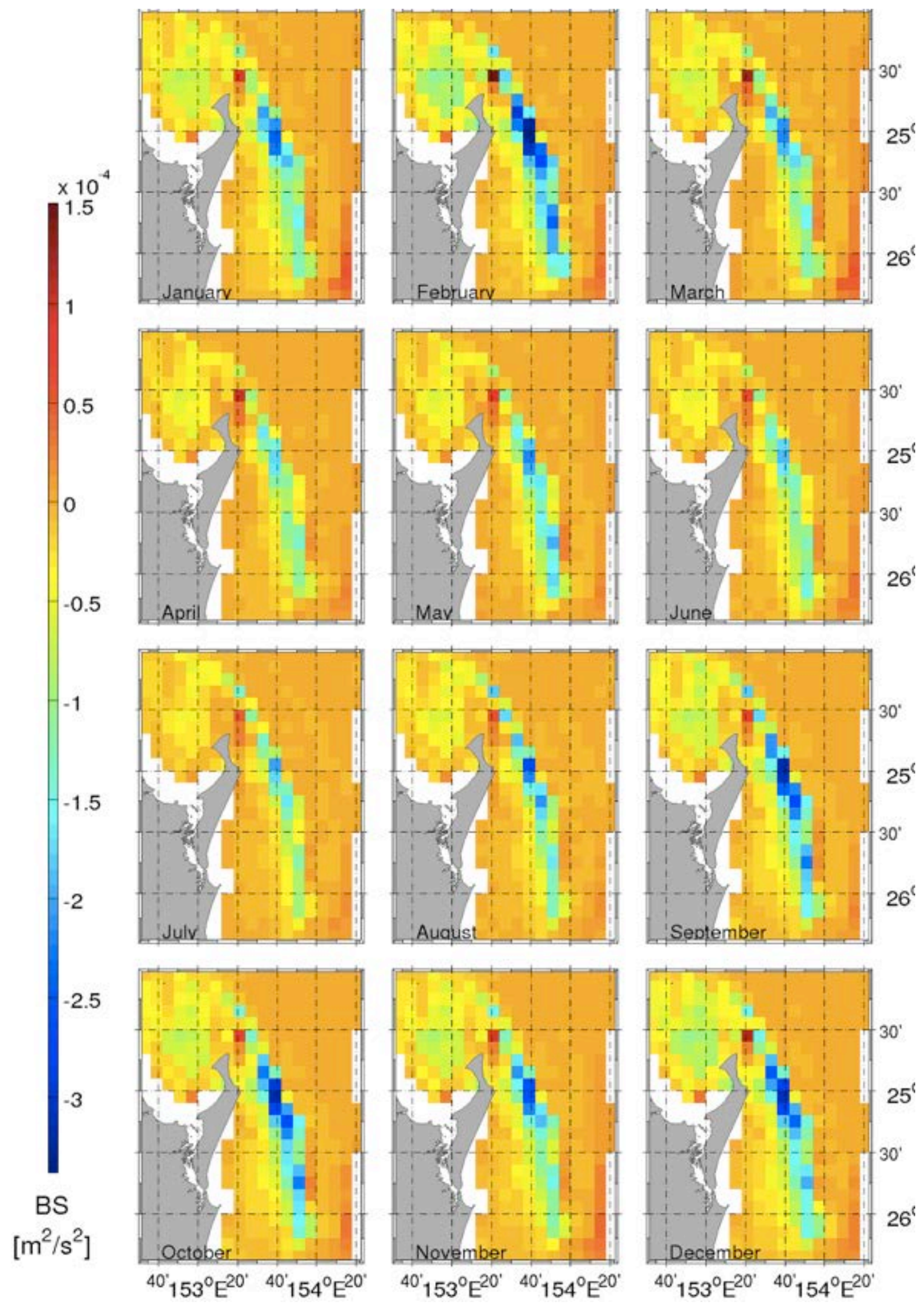

Figure 7: Monthly bottom layer stress climatology $\tau_{y w}\left(N \cdot m^{-2}\right)$. BRAN 3.5 data provided by Bluelink (Oke et al. 2008). 


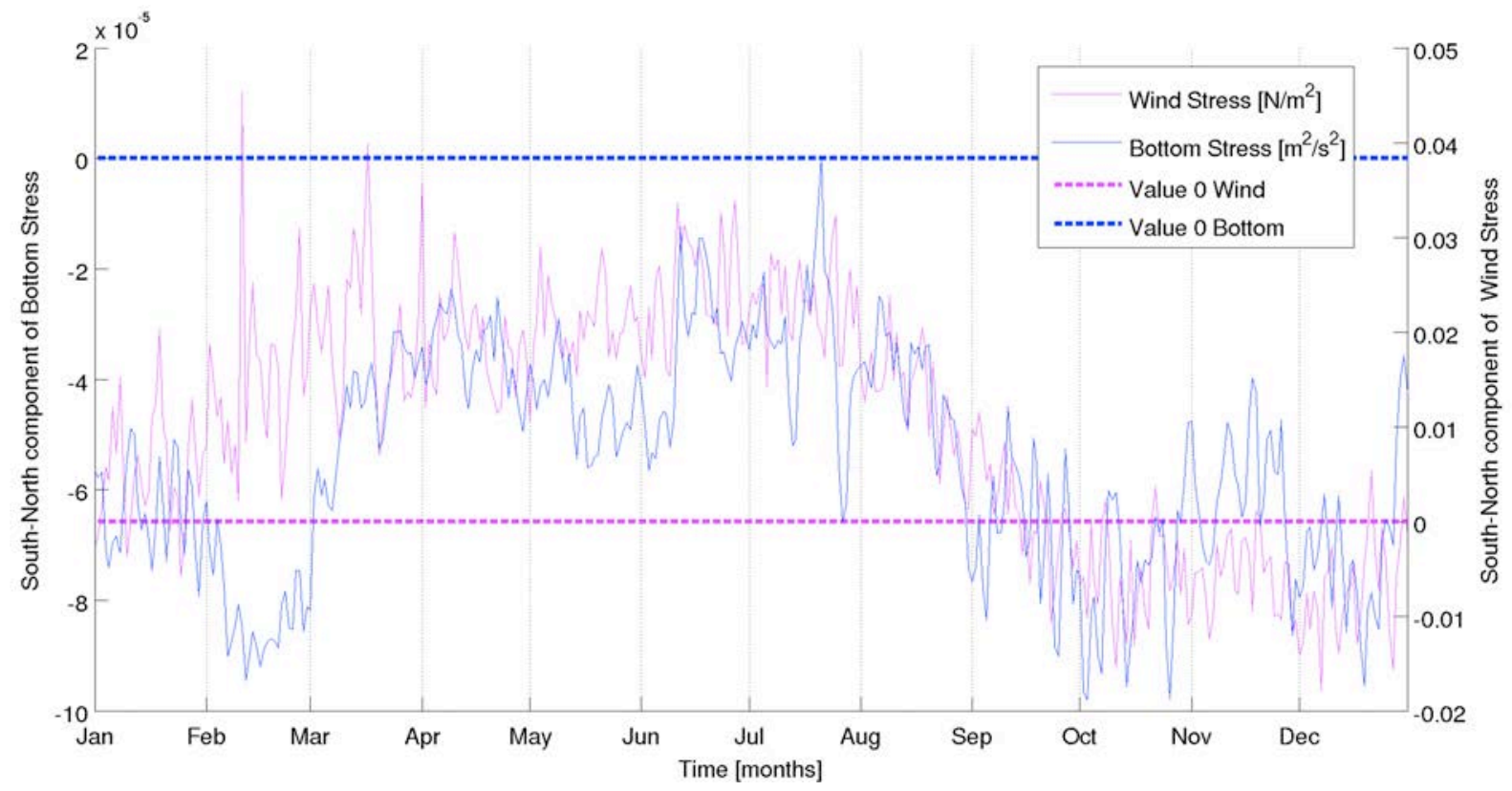

Figure 8: Average monthly reference sea surface level wind stress $\tau_{\mathrm{yw}}\left(\mathrm{N} \cdot \mathrm{m}^{-2}\right)$ from Sandy Cape measurements (see Figure 1) and bottom layer stresses $\tau_{\mathrm{yb}}$ $\left(\mathrm{N} \cdot \mathrm{m}^{-2}\right)$ from BRAN3.5 data (Oke et al. 2008). Bottom stresses are shown as averaged for the region characterised by P2 events, i.e. about $153.25^{\circ} \mathrm{E}-154.0$ ${ }^{\circ} \mathrm{E}$ and $24.5 \mathrm{oS}-26.5^{\circ} \mathrm{S}$. 


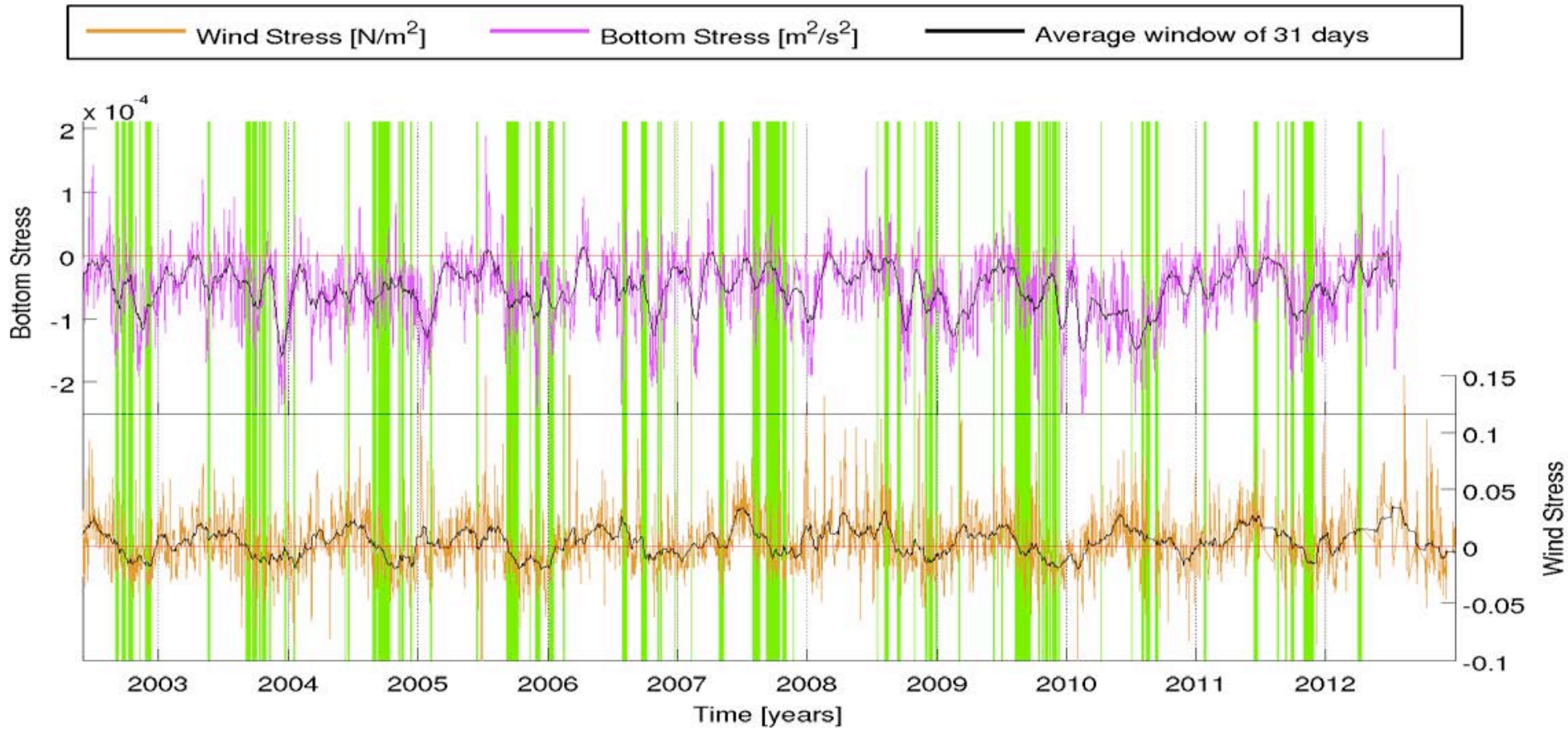

Figure 9: Daily averaged alongshore wind stress $\tau_{\mathrm{yw}}\left(\mathrm{N} \cdot \mathrm{m}^{-2}\right)$ from wind measurements as Sandy Cape (see Figure 1), daily averaged alongshore bottom layer stress $\tau_{\mathrm{yb}}\left(\mathrm{m}^{2} \cdot \mathrm{s}^{-2}\right)$ from BRAN3.5 data (Oke et al. 2008) and averaged for the region southeast of Fraser Island. The vertical bars indicate Chl-a P2 events. The thicker line represents a 31-day moving average. 